Akademie, politika

a akademie jako politika:

Ke kritice „rozšî̃eného“ pojetí

akademické svobody

\author{
Academia, Politics, and Academia as \\ Politics: A Critique of the "Extended" \\ Concept of Academic Freedom
}

Acta Fakulty filozofické Západočeské univerzity v Plzni /

West Bohemian Review of Social Sciences \& Humanities 2020, Vol. 12 (2), 19-43 DOI: https://doi.org/10.24132/actaff.2020.12.2.2 https://actaff.zcu.cz/ ISSN 2336-6346

\title{
Libor Benda*
}

University of West Bohemia, Czech Republic

\begin{abstract}
There has been a significant growth of interest in the topic of academic freedom in recent years, predominantly with regard to the emergence of several new and unprecedented phenomena within the academic environment that allegedly threaten or directly undermine academic freedom both on the individual and institutional levels. One of the responses to these observations is the attempt to redefine academic freedom in political terms, since the traditional concept of academic freedom, grounded in the purely epistemological notions of rationality, objectivity, and truth, is becoming regarded as incapable of facing the challenges and overcoming the obstacles encountered by academia in the present circumstances. It has been argued that instead of being limited only to epistemic responsibilities of academics, academic freedom should be "extended" to include the political responsibility of academics as well and should therefore provide the academics first and foremost with an appropriate set of political rights to fulfil their political role. This paper critically examines both the theoretical background behind this political shift in thinking about academic freedom as well as its prospective consequences for the academic profession and academia as a whole. While there are sound theoretical reasons that favour the "extended" version against the traditional concept of academic freedom, I argue that the associated political extension of academic responsibilities blurs the line between academic and political affairs and puts academia in danger of becoming an openly political - rather than authentically academic - institution. The paper is concluded by a tentative suggestion of an alternative account of academic freedom: one that takes seriously the theoretical weaknesses of the traditional version but maintains at the same time a clear and sharp distinction between academic and political matters.
\end{abstract}

\section{Keywords}

academia, academic freedom, academic profession, academic responsibility, politics 4.0 International License.

\footnotetext{
* Corresponding Author: Libor Benda, Katedra filozofie, Fakulta filozofická Západočeské univerzity v Plzni, Sedláčkova 19, 30614 Plzeň. E-mail: Libor.Benda@gmail.com.
} 


\section{Úvod}

Téma akademické svobody je specifické tím, že ačkoliv mají otázky, které jsou s ním spojeny, bezprostřední relevanci pro výkon akademické profese i pro fungování akademie jako takové, v rámci akademického výzkumu je mu jen zrrídkakdy věnována kritická pozornost, a patří tak spíše mezi témata okrajová. V posledních letech lze nicméně pozorovat výrazný nárůst zájmu o tuto problematiku, a to především ve spojitosti s řadou nově pozorovaných a bezprecedentních jevů a trendů v akademickém prostředí (i mimo ně), které akademickou svobodu dle tvrzení mnohých autorů závažným způsobem ohrožují či zcela podrývají, a to v rovině institucionální i individuální. ${ }^{1}$ Tyto nově pozorované hrozby mají rozličný původ. Na jedné straně je řeč o systémových hrozbách, spojených s postupnou politicko-ekonomickou transformací akademického prostředí. Jako př́klad lze v tomto ohledu uvést ekonomické tlaky vyvíjené na akademické instituce v souvislosti s pronikáním principů tzv. akademického kapitalismu do akademického prostředí, v jehož důsledku je akcentován sociální „,impakt“ a ekonomická profitabilita akademických badatelských i pedagogických aktivit (Slaughter, Leslie 1997; Slaughter, Rhoades 2004). Podobně jsou hodnoceny i některé důsledky plynoucí pro akademické prostředí z přechodu k tzv. manažerskému modelu univerzity, tedy zejména důraz na vykazatelnost akademické práce či metodika hodnocení vědecké práce opírající se o metrické indikátory vědeckého „výkonu“, jež v mnoha ohledech zvýhodňují zejména krátkodobě orientované a komparativně „méně odvážné“, konzervativní trajektorie výzkumu. V oblasti výuky lze v této souvislosti zase zmínit důraz na počet studentů a na uspokojování jejich potřeb, který může mít negativní dopad na kvalitu výuky (Foster et al. 2015; Müller 2014; Kremakova 2016; Shore, Wright 2000). Jak upozorňuje řada autorů, v rámci manažerského modelu je akademie transformována do pomyslné „firmy“, jejíž chod je řízen primárně ekonomickými faktory, jež mohou ovšem stát v cestě původní a fundamentální funkci akademických institucí, za níž je tradičně pokládána nezávislá výzkumná a pedagogická činnost (Parker, Jary 1995; Hayes, Wynyard 2002; Besley, Peters 2005). Vedle hrozeb systémových se ale stále častěji objevují zprávy také o případech politicky motivovaného omezování akademických svobod, počínaje izraelskou okupací ${ }^{2}$ palestinského území na Západním břehu Jordánu a v Pásmu Gazy (Butler 2006, 2015), přes rozhodnutí madarského premiéra Viktora Orbána o zrušení genderových studií na budapeštské Středoevropské univerzitě (Oppenheim 2018; Kent, Tapfumaneyi 2018) a uzavření archivu mad’arského marxistického filosofa a intelektuála Györgyho Lukácse (Erdélyi 2018), až po uzavření více než desítky tureckých univerzit a perzekuci tisíců tureckých akademiko̊ ze strany tureckého prezidenta Recepa Tayyipa Erdo?ana z důvodu jejich participace na mírové kampani za ukončení tureckých vojenských operací v kurdském regionu (Butler 2017, 2018; Butler, Ertür 2017).

Všechna tato pozorování vedou nejen ke zvýšenému zájmu o otázku, zda stávající formální garance principů akademické svobody poskytuje také dostatečnou záruku jejich faktické realizace v praxi, ale do popředí se v rámci probíhající diskuse dostává otázka podstatně fundamentálnější povahy: Jaký je (resp. má být) vůbec obsah a smysl akademické svobody? Právě zejména na pozadí výše zmíněných př́padů politického zasahování do práv akademických pracovníků se objevují ar-

\footnotetext{
${ }^{1}$ Tím ovšem nechci říci, že by problematice akademické svobody nebyla až donedávna věnována žádná pozornost. Zejména ve Velké Británii a USA je toto téma v souvislosti s politickou rolí univerzity př́ležitostně diskutováno již přinejmenším od šedesátých let minulého století, kdy byl pojem akademické svobody hojně skloňován v souvislosti s politicky motivovanými aktivitami studentských hnutí požadujících radikální demokratizaci univerzit, jako tomu bylo např́klad v letech 1967-1969 na London School of Economics (Barendt 2010: 85-89).

${ }^{2}$ Jsem si vědom toho, že názory na povahu a legitimitu izraelských vojenských operací na palestinském území se mohou lišit, jak jsem byl upozorněn jedním z recenzentů. Používám-li zde (a dále v textu, kde bude o této kauze podrobněji pojednáno) bez jakékoliv další argumentace slovo „okupace“, nečiním tak za účelem prosazování jakéhokoliv politického postoje vůči př́islušným událostem, ale držím se zkrátka zpo̊sobu, jakým je o této kauze pojednáváno v rámci aktuální debaty o akademické svobodě, která je předmětem zájmu tohoto článku.
} 
gumenty ve prospěch názoru, že tradiční pojetí akademické svobody, opírající se o osvícenské pojmy racionality, objektivity a pravdy, se ukazuje jako bezzubé a neschopné efektivně řešit nové výzvy, kterým musí koncept akademické svobody (a akademie jako taková) v současných společenských podmínkách čelit. Jestliže je totiž akademická svoboda pojímána toliko z perspektivy epistemické funkce akademických institucí, tedy jako soubor práv, jenž má garantovat nezávislost a nezaujatost produkovaného a předávaného vědění, pak se na ni lze jen velmi obtížně odvolávat $\mathrm{v}$ př́padech, které byly uvedeny výše: události v Turecku i na palestinském území mohou být nanejvýše hodnoceny jako politicky politováníhodné, avšak nikoliv jako zásahy do akademických svobod, nebot zde stricto sensu nedochází k jakémukoliv přímému ohrožování nezávislosti výzkumu či výuky; a události v Madarsku pak lze z pohledu některých zastánců tradičního osvícenského pojetí akademické svobody dokonce nahlížet jako kroky k větší politické (či ideologické) vyváženosti akademického prostředí, a v tomto smyslu tedy i - paradoxně - k jeho větší nezaujatosti a politické neutralitě. ${ }^{3}$ Kritikové tradičního pojetí akademické svobody jsou ovšem toho názoru, že ve všech uvedených případech není o faktickém zasahování do akademických svobod sebemenších pochyb. Svoje tvrzení opírají o argument, že akademická svoboda v tradičním smyslu může být plně realizována pouze v takových společenských podmínkách, kde jsou v prvé řadě dodržovány základní demokratické principy a lidská práva, jakými jsou intelektuální svoboda či svoboda slova, a jakýkoliv útok proti těmto fundamentálním politickým svobodám je dle jejich názoru proto nutno vnímat i jako útok na akademickou svobodu jako takovou. Na tomto základě je pak rozvíjen argument, že akademickou svobodu od těchto všeobecných politických svobod nelze v praxi oddělit a že její tradiční chápání ve smyslu politické neutrality a nezávislosti akademických institucí je třeba nahradit „rozšǐřeným“, politizovaným pojetím. V jeho rámci již akademická svoboda není definována jako svoboda čistě profesionální, ale jako svoboda explicitně politická, a vzájemná hranice mezi profesionální a politickou odpovědností akademických pracovníků se v tomto pojetí zcela vytrácí. Takto pojímaná akademická svoboda má garantovat nikoliv právo vykonávat akademickou profesi nezávisle na politických zájmech - takové úsilí je nahlíženo

\footnotetext{
${ }^{3}$ Takový postoj je pochopitelně mimořádně kontroverzní, nicméně lze se s ním v určité podobě setkat např. v Horowitz (2006, 2009); Horowitz, Laksin (2009); Williams (2016). Z pohledu Horowitze a Williamsové je jednou z hlavních současných hrozeb pro akademickou svobodu podřízenost akademického prostředí, zejména v oblasti humanitních a společenských věd, liberálně-levicové politické ideologii. $\mathrm{V}$ jejím důsledku se podle Williamsové akademické prostředí stává kulturou konformity, v níž jsou různé názory posuzovány nikoliv nezaujatě, ale na základě jejich politického a hodnotového zakotvení, přičemž ty myšlenky, které jsou v rozporu s dominantním liberálně-levicovým hlediskem, nemají šanci uspět. Jak sama uvádí: „Pseudoradikální levicový konsenzus, který prostupuje současným univerzitním prostředím, na jednu stranu vede $k$ tomu, že kritika neoliberalismu, populárních médii a konzumu vám automaticky zaruči podporu kolegư, kteři budou rozhodovat o prijijetí vašeho článku $k$ publikaci nebo o vašem kariérním postupu. Na druhou stranu, pokud se nezmíníte o důležitosti feminismu, sociálního státu nebo ochrany životního prostredí, vaše práce bude velice pravděpodobně odmítnuta" (Williams 2016: 80). Akademická svoboda je v těchto podmínkách dle jejího názoru nahrazena akademickou spravedlností v tom smyslu, že akademické prostředí přestává být místem skutečně svobodného myšlení, ale pouze takového, které je politicky přijatelné. Horowitz současnou situaci hodnotí podobně, přičemž jako východisko navrhuje prosazení principu tzv. intelektuální diverzity, který má zajistit politickou vyváženost akademického prostředí, a tím i jeho politickou neutralitu. Za účelem dosažení intelektuální diverzity Horowitz požaduje zavedení několika opatření: za prvé, vzhledem k jednoznačné převaze liberálně-levicově orientovaných akademiků by dle jeho názoru měli být na akademické pozice přednostně přijímáni ti uchazeči, kteří se přiklánějí ke konzervativně-pravicovým politickým hodnotám; a za druhé, měla by být zajištěna i ideologická vyváženost obsahu výuky - tj. liberálním autorům a myšlenkám by měl být v rámci výuky věnován stejný prostor jako těm konzervativním. Není třeba zvláště upozorňovat na to, že takový návrh je značně kontroverzní. Požadavek „kádrování“ akademických pracovníků na základě jejich politického přesvědčení, stejně jako požadavek kontroly politického obsahu přednášené látky v rámci výuky, lze jen stěží označit za krok směrem k depolitizaci akademického prostředí a k rehabilitaci akademické svobody, ale naopak představuje zcela explicitní omezování akademické svobody na základě politických důvodů, jež připomíná praktiky autoritářských a nedemokratických režimů. Kritický rozbor takového pojetí akademické svobody je nicméně námětem na samostatnou studii; zde se jím nebudu podrobněji zabývat.
} 
jako politicky nezodpovědné -, ale naopak právo vykonávat akademickou profesi explicitně za účelem prosazování specifických politických ideálů a hodnot.

Záměrem tohoto příspěvku je podrobit toto „rozšiřené“ pojetí akademické svobody kritickému rozboru a poukázat na jeho limity, jakož i na potenciálně nebezpečné důsledky, které z něj plynou, a to nejen pro chápání smyslu akademické svobody, ale i pro úvahy o funkci a smyslu akademie jako takové. Jak se pokusím ukázat, argumenty nacházející se v jeho základech mají silnou oporu v dostupných společenskovědních poznatcích a jako takové zasluhují seriózní pozornost a je třeba je brát nanejvýše vážně. Konkrétní způsob interpretace těchto argumentů ze strany zastánců tohoto pojetí, jakož i důsledky, které z nich jsou vyvozovány pro myšlení o obsahu a smyslu akademické svobody, se však při bližším pohledu ukazují jako obtížně udržitelné. Můj postup bude následující: Výchozím bodem mého př́ispěvku bude nahlédnutí do dějin akademické svobody, v jehož rámci nejprve pojednám o původních motivech, které podnítily rozpracování a prosazení tohoto konceptu jakožto souboru nezbytných práv, jenž měl garantovat schopnost akademických institucí vykonávat svoji výzkumnou a vzdělávací funkci s plnou profesionální integritou. Na tomto pozadí pak budu věnovat pozornost postupné transformaci tohoto konceptu v průběhu 20. století se zaměřením na teoretické důvody, v jejichž světle se původní osvícenské pojetí akademické svobody ukazuje jako intelektuálně naivní a neschopné adekvátně plnit svůj účel, a které se nacházejí v základech alternativního, „rozššřreného“ pojetí. To bude podrobně představeno v následující části, a to prostřednictvím rozboru politické reinterpretace pojmu akademické svobody v textech kritické teoretičky Judith Butlerové, jedné z klíčových aktérek probíhající debaty ohledně akademické svobody a přední zastánkyně tohoto pojetí. V této souvislosti bude věnována pozornost konkrétně jejím příspěvkům do debaty ohledně zmíněného palestinského bojkotu izraelských univerzit. Butlerová na př́kladu této kauzy rozpracovává systematickou kritiku tradičního osvícenského chápání akademické svobody i funkce akademických institucí a argumentuje ve prospěch rozšíření akademických profesionálních odpovědností o odpovědnost politickou, na základě čehož současně vznáší požadavek odpovídající redefinice akademické svobody jako svobody politické, která by akademickým pracovníkům garantovala právo se politicky angažovat ve prospěch demokratických hodnot a ideálů solidarity, rovnosti a úcty k člověku. Tato interpretace akademické svobody jako svobody politické bude následně podrobena kritickému rozboru, v jehož rámci předložím argument ve prospěch názoru, že ztotožnění akademické svobody s politickou svobodou je - navzdory poznatkům, v nichž toto ztotožnění nachází svoji oporu - z řady důvodi̊ neudržitelné a mimo jiné vystavuje riziku i akademickou integritu jako takovou. Přestože pokládám za nezbytné brát teoretické motivy v pozadí tohoto pojetí se vší vážností, pokusím se ukázat, že je z nich pro uvažování o akademické svobodě třeba vyvodit odlišné důsledky, než je setření jakékoliv hranice mezi akademickou a politickou svobodou - tedy alespoň tehdy, pokud si má akademická svoboda v jakémkoliv smyslu uchovat svoji „akademičnost“. Inspirací pro nastíněné alternativní východisko bude mj. weberovské vymezení hranice mezi akademií a politikou a s ním související koncept „akademizace“, jejž v kontextu debaty o akademické svobodě rozpracovává Stanley Fish.

\section{Od politické nezávislosti k politické odpovědnosti}

Akademická svoboda je v kontextu dějin univerzity (a akademie obecně ${ }^{4}$ ) - možná poněkud překvapivě - relativně mladým konceptem. Je sice pravda, že dějiny toho, co bychom mohli pojmenovat jako „ideu“ akademické svobody, lze podle některých autorů vysledovat přinejmenším až k Sókratovi, jehož př́pad lze vykládat jako vůbec první střet mezi akademickou svobodou

\footnotetext{
${ }^{4}$ Vedle univerzit bychom za součást akademie označili i postupně vznikající vědecké společnosti a jiné nezávislé badatelské instituce. Aktuálně se akademií v České republice míní vysoké školy (univerzity), Akademie věd ČR a resortní výzkumné ústavy jednotlivých ministerstev.
} 
jakožto svobodou intelektuální na jedné straně a politickou mocí na straně druhé. Takový výklad by byl ovšem zavádějícím anachronismem, jelikož akademickou svobodu je jako svobodu profesionální nezbytné od svobody intelektuální odlišovat, a z toho důvodu nedává dobrý smysl o ní uvažovat dříve než v kontextu rozvoje univerzity jako svébytné instituce, jakož i v kontextu akademické profese jako specifického povolání. Již od vzniku prvních univerzit, který lze datovat zhruba na konec 11. a počátek 12. století, představovalo jejich postavení ve společnosti a zejména jejich vztah k externím společenským autoritám specifický problém. Jak uvádí historik Geoffrey Stone, obraz středověké univerzity jako instituce zcela podřízené církevním zájmům je značně zavádějící, nebot univerzity - přestože podléhaly autoritě církve - byly v jistém ohledu v podstatě samosprávné a mohly se těšit značné míre nezávislosti přinejmenším v oblasti volby svých představitelů a interního rozhodování o praktických záležitostech spojených s chodem univerzity. Stejně tak mylná by ovšem byla představa univerzity jako místa, které by církevnímu vlivu nepodléhalo vůbec. Ačkoliv je pravda, že církev nezasahovala přímo do institucionálních rozhodnutí a do každodenních záležitostí univerzity, tato nezávislost již zdaleka neplatila pro vědění, jež bylo na univerzitách kultivováno a dále předáváno. Učení rozvíjené a předávané na univerzitách mělo ze strany církve pevně stanovené limity. Jak uvádí Jiří Chotaš, středověké univerzity měly především „pěstovat racionálni nauky jako obranu pred kacírskými hnutími, vychovávat nové adepty pro církevní úřady a posilovat papežovu autoritu vůči světským panovníkưm a feudáliom " (Chotaš 2015: 73). Jelikož církev netolerovala šíření jakýchkoliv pochybností a nejistot ohledně obsahu křestanské nauky, pro univerzity byla v tomto období závazná doktrína, podle níž muselo být veškeré učení konzistentní se systémem pravd zakotveným v křestanských dogmatech (Stone 2015: 2).

Pokroky na poli vědy ovšem měly za následek vznik četných rozporů mezi náboženskou doktrínou na jedné straně a poznáním rozvíjeným v prostředí univerzity na straně druhé. ${ }^{5}$ Tyto konflikty, v jejichž středu se opět nacházela idea akademické svobody stojící proti politickým snahám o její omezení ze strany církve, jakož i zámořské objevy a střetávání se s novými kulturami, postupně oslabovaly autoritu církve postavení křestanských dogmat a připravily základy pro rozvoj osvícenství spočívajícího na ideálech racionality, objektivity, pravdy a společenského pokroku. Byl to právě tento intelektuální a společenský vývoj v Evropě, který umožnil vznik „nové“, autonomní univerzity opírající se o ideál akademické svobody tak, jak jí rozumíme dnes - ideál, který byl teprve v tomto období vůbec poprvé explicitně rozpracován a vymezen. Princip akademické svobody byl v návaznosti na společenské a intelektuální změny spojené s německým osvícenstvím poprvé formulován německým (pruským) filosofem a jazykovědcem Wilhelmem von Humboldtem, který byl v roce 1809 pruským králem jmenován ministrem vzdělání a pověřen úkolem reformovat zastaralý pruský vzdělávací systém (Barendt 2010: 120). Humboldtovy reformy vedly ještě téhož roku k založení nové, liberálně orientované Berlínské univerzity, ${ }^{6}$ jejímiž základními východisky byly snaha o výuku studentů směrem ke schopnosti kriticky myslet spíše

\footnotetext{
${ }^{5}$ Dobře známým - a také velice názorným - příkladem v této souvislosti je proces s Galileem Galileim, astronomem, který byl v důsledku zveřejnění svých pozorování potvrzujících platnost Koperníkova heliocentrického modelu vesmíru pronásledován inkvizicí, bylo mu vyhrožováno mučením, byl donucen zřeknout se veřejně svých názorů a doživotně držen v domácím vězení. Podobný konflikt (či spíše obavy z možného konfliktu) ostatně doprovázel i samu publikaci Koperníkova spisu De Revolutionibus Orbium Coelestium, k němuž jeho vydavatel, luteránský teolog a protestantský reformátor Andreas Osiander, v roce 1543 přidal bez Koperníkova vědomí anonymní předmluvu, v níž uvedl, že předložený heliocentrický model si nenárokuje faktickou pravdivost - tj. nemá být interpretován jako doslovný popis fyzikální reality -, ale má sloužit toliko jako užitečný matematický nástroj pro výpočet a předpověd pohybu nebeských těles; jako takový tedy má být pojímán pouze v instrumentálním slova smyslu (viz Kuhn 1957: 187).

${ }^{6}$ Později přejmenované na Univerzitu Fridricha Viléma, Univerzitu pod lipami, a od roku 1949 známé jako Humboldtova univerzita.
} 
než ke zvládnutí určitých praktických dovedností, propojení výzkumu a výuky, a autonomie univerzity, tj. akademická svoboda v badatelské i pedagogické oblasti (Zimmer 2015: 240). ${ }^{7}$

Potřeba akademické svobody jako základního principu fungování univerzity (a akademie obecně), na niž Humboldt upozorňuje ve svém memorandu „O vnitřní a vnější organizaci vyšších vědeckých ústavů v Berlíně“ (Humboldt 2015: 340-341), byla motivována několika důvody. Prvním byla pochopitelně historická zkušenost s vnějšími zásahy do oblastí produkce i předávání vědění a negativními dopady těchto zásahů - at už v rovině osobní, intelektuální či celospolečenské. Kromě toho, Humboldt byl zastáncem představy, že smysl univerzity spočívá především v kultivaci obecného vzdělání (Bildung), umožňujícího porozumění světu jako celku v jeho rozmanitosti. Právě v tomto typu vědění Humboldt spatřoval jak možnost komplexního osobního rozvoje, tak i možnost zlepšení světa jako takového. I proto se dle jeho názoru mělo univerzitní vzdělání dotýkat především „velkých“ duchovních a mravních otázek ohledně míru, spravedlnosti, vzájemného soužití různých kultur, kosmopolitismu atd. Univerzitní vzdělání podle něj naopak nemělo být „prakticky“ orientováno ve smyslu pouhé přípravy studentů na budoucí zaměstnání, a takto tedy být podřízeno politicko-ekonomickým zájmům. Jak zmiňuje Edward Shils (2015: 384), univerzita podle Humboldta neměla být „,strojem na výrobu odborníků “, po nichž je aktuálně poptávka, ale její činnost měla být primárně podřízena univerzálnímu ideálu hledání pravdy. Princip akademické svobody měl univerzitám zajistit právě v tomto ohledu tolik potřebnou nezávislost na př́ípadných vnějších politických a ekonomických požadavcích, intervencích a tlacích.

Samostatným důvodem pro Humboldtův požadavek akademické svobody pak byl státní status německých univerzit, a tedy i jejich zaměstnanců. Podle Humboldta univerzity neměly být zcela oddělené od státu, jelikož právě stát měl odpovídat za zajištění svobody výzkumu a výuky prostřednictvím ochrany univerzity před vlivem církevních a soukromých zájmů, nicméně zde měly pravomoci státu vůči univerzitám současně končit (Barendt 2010: 121). V praxi tomu tak ovšem nebylo a stát $\mathrm{s}$ odkazem k této své zodpovědnosti mnohdy zasahoval do vnitřních záležitostí univerzity, např. v podobě vlastního jmenování univerzitních profesorů, nezřídka v rozporu se stanovisky fakulty, a v některých př́ipadech i v podobě jejich odvolávání z důvodu jejich údajné politické angažovanosti. Známým př́padem v této spojitosti je odvolání celkem sedmi profesorů z Göttingenské univerzity, mezi nimiž byli kupř́kladu i bratři Jacob a Wilhelm Grimmové, a to na základě jejich veřejného protestu proti rozhodnutí krále o zrušení hannoverské ústavy v roce 1837. Státní status univerzit měl tedy za následek, že němečtí univerzitní profesoři - jakožto státní zaměstnanci - podléhali státní moci a jako takoví mohli být kdykoliv odvoláni, a to navzdory Humboldtově snaze o pravý opak. ${ }^{8}$ Jak v této souvislosti podotýká Eric Barendt (2010: 121), oficiálním zdůvodněním těchto kroků ze strany státu přitom byla nezřídka paradoxně právě ochrana akademické svobody.

Tyto a další konflikty mezi akademickou sférou a státní mocí, jakož i nemožnost akademických pracovníků bránit se z pozice státních zaměstnanců před rozhodnutími státních úředníků, postupně vedly k legislativnímu zakotvení principů akademické svobody. Nejprve tomu tak bylo ve Frankfurtské ústavě z roku 1849, pak ve Výmarské ústavě z roku 1919 a od roku 1948 dodnes je akademická svoboda v Německu (jako tzv. Wissenschaftsfreiheit) garantována Německým základním zákonem (Barendt 2010: 121-122). Právní zakotvení akademické svobody v Německu

\footnotetext{
${ }^{7}$ O Humboldtových reformách pruského vysokoškolského vzdělávání v kontrastu s podstatně odlišnými a v některých ohledech zcela protichůdnými reformami vysokého školství ve Francii v letech 1789-1810 podrobněji pojednává Jiří Chotaš (2015). Jak uvádí, v protikladu k Humboldtovým reformám bylo jejich součástí nejen ostré oddělení výzkumu od výuky, ale také centralistické řízení a kontrola vyšších vzdělávacích institucí ze strany státu: „Stát začal až do nejmenšich podrobností určovat studijní programy a zkušební rády a dohližet na politickou a náboženskou loajalitu během výuky. Pod hrozbou disciplinárního ř́zení si stát u učitelů i studentů vynucoval zachovávání takřka vojenské discipliny" (Chotaš 2015: 81).

${ }^{8}$ Shils v této souvislosti uvádí, že Humboldt „chtěl, aby se stát zdržel zasahování do akademických záležitostí", přestože byl v této věci „zdrženlivý či o ní mlčel" (Shils 2015: 384).
} 
přitom nemělo vliv na její obsah - ten zůstal v podstatě stejný od prvotní Humboldtovy koncepce z počátku 19. století -, ale jeho význam lze spatřovat v tom, že univerzitám byla takto garantována nezávislosti i před státem, tj. spočíval v možnosti akademických pracovníků i institucí bránit se proti státním rozhodnutím, která akademickou svobodu (byt mnohdy za účelem její údajné „ochrany“) ohrožují či př́mo potlačují. Humboldtem formulované principy akademické svobody ještě na konci 19. století rovněž ovlivnily diskusi o akademii, její společenské roli a nezbytných předpokladech jejího odpovědného fungování v USA a zde byly na základě podobných motivů jako v Evropě prosazeny a prvně oficiálně formulovány roku 1915 v tzv. „Deklaraci principů akademické svobody“ (celým původním názvem „Declaration of Principles of Academic Freedom and Tenure“; AAUP 1915), přičemž roku 1940 byly následně upřesněny v tzv. „Prohlášení o principech akademické svobody“ (celým původním názvem „Statement of Principles on Academic Freedom and Tenure"; AAUP 1940). V průběhu druhé poloviny 20. století se pak rozšśřily i naprř́č evropským kontinentem, jakož i ve Velké Británii, a staly se součástí řady ústav evropských zemí.

Skutečnost, že akademická svoboda byla prosazována v rozličných geografických a sociokulturních kontextech, měla za následek více či méně výrazné odlišnosti v konkrétních trajektoriích, jimiž se vývoj tohoto konceptu na různých místech ubíral, a tudíž i v konkrétních přístupech k výkladu jeho obsahu. Navzdory těmto rozdílům lze ovšem identifikovat několik specifických charakteristik, které jsou všem těmto dostupným výkladům společné a které jsou s konceptem akademické svobody od jeho vzniku inherentně spjaty. Tou první a nepochybně nejdůležitější z nich je profesionálni status akademické svobody. Akademická svoboda byla rozpracována a prosazena jako specifický soubor výsad, jenž náleží jen a pouze vykonavatelům akademické profese, a jenž je tudíž esenciálně spjat s aktivitami a odpovědnostmi, které tuto profesi definují. Jako takovou je proto akademickou svobodu nutno di̊sledně odlišovat od příbuzných, ale zásadně odlišných svobod, jako jsou svoboda intelektuální a svoboda slova. Jak podotýká Eric Barendt, akademická svoboda bývá mnohdy vykládána v termínech všeobecné svobody slova, či případně jako „neomezená“ svoboda slova, avšak takový výklad je zavádějící mj. z toho důvodu, že ignoruje rozdíl mezi akademickou svobodou jakožto profesionální svobodou na jedné straně a svobodou slova jakožto všeobecnou politickou svobodou na straně druhé. Pokud by akademická svoboda byla zkrátka a dobře svobodou slova, pak není jasné, v čem by měla spočívat její specifická „akademičnost“; a pokud má její „akademičnost“ spočívat právě v její „neomezenosti“ oproti všeobecné svobodě slova, není docela dobře jasné, jak tuto „neomezenost“ chápat ani jak odůvodnit její legitimitu. Jestliže je všeobecná svoboda slova jedním z fundamentálních lidských práv, jež je garantováno všem lidem bez rozdílu, pak vůbec není jasné, proč by akademičtí pracovníci měli být právě v tomto ohledu jakkoliv „Svobodnější“ než ostatní občané, či - naopak - proč by měla být svoboda slova „řadových“ občanů jakkoliv „omezená“ v kontrastu s „neomezenou“ svobodou slova akademických pracovníků (srov. Barendt 2010: 18-19). Navíc, představa akademie jako místa neomezené svobody slova je jednoduše zavádějící a naivní, jelikož akademičtí pracovníci jsou v rámci vykonávání své profese $\mathrm{v}$ podstatné míre naopak svazováni specifickými standardy a požadavky, jež na ně tato profese klade. Daleko spíše než jakoukoliv extenzí svobody slova je tedy akademická svoboda naopak souborem určitých omezení a hranic ohledně toho, co ještě je (resp. může být) legitimní součástí výkonu akademické profese a co už nikoliv. Tak např. univerzitní učitel zcela jistě nemá svobodu v rámci kurzu matematiky přednášet o postmoderní literatuře, kvantové teorii nebo třeba o americké zahraniční politice - a to bez ohledu jak na akademikovy kompetence, tak i na aktuálnost či eventuální př́nnos takové diskuse, nebo její atraktivitu pro posluchače. Stejně tak nemá akademický pracovník - at už v rámci výuky nebo jiné akademické činnosti - právo vyjadřovat se rasisticky, sexisticky, obscénně či jakkoliv jinak nevhodně (tj. jakkoliv v rozporu se zákonem a dobrými mravy). Tvrzení, že je tímto jakkoliv omezována jeho akademická svoboda, 
je zcela absurdní, a to právě z toho důvodu, že jeho profesionální integrita, tj. jeho schopnost plnohodnotně a odpovědně vykonávat svoji profesi, tímto není jakkoliv ohrožena (Barendt 2010: 18-19).

S tím pak úzce souvisí druhý klíčový atribut akademické svobody, kterým je inherentní závislost jejîho obsahu na výkladu funkce akademie jako takové. Jestliže je akademická svoboda souborem profesionálních výsad, které jsou nezbytné k plnohodnotnému výkonu akademické profese, pak lze jejich vlastní obsah interpretovat různými způsoby podle toho, jak konkrétně bude chápána funkce akademických institucí a co bude řazeno mezi fundamentální povinnosti a odpovědnosti akademických pracovníků. V tomto ohledu je potřebnost akademické svobody tradičně zdůvodňována s odkazem k epistemické funkci akademických institucí. Ta spočívá v tom, že úkolem akademických institucí - a jednotlivých akademických pracovníků - je zkrátka a dobře podílení se na nezaujatém rozvoji objektivního poznání a na hledání pravdy, a to bez ohledu na jakékoliv širší implikace a dopady poznání, které je výsledkem této aktivity. Akademická svoboda je pak na základě tohoto argumentu nezbytným předpokladem právě toho, aby akademičtí pracovníci mohli odpovědně plnit tuto svoji roli. Pravda je z pohledu tohoto argumentu pojímána jako hodnota o sobě a jsou to právě akademičtí pracovníci, jejichž profesionální odpovědností je produkovat pravdivé poznání a předávat je dále, stejně jako např. zdravotníci nesou profesionální odpovědnost za záchranu lidských životů. Akademická svoboda v tomto ohledu představuje specifický soubor výsad, který má akademickým pracovníkům garantovat možnost plnit tuto svoji pracovní povinnost bez jakýchkoliv omezení, a to prostřednictvím zajištění autonomie akademických institucí a jejich ochrany před jakýmikoliv vnějšími vlivy, které by mohly nezaujatost, objektivitu a celkovou integritu akademické práce kompromitovat. Východiskem tohoto argumentu je přitom tradiční, racionalistické pojetí poznání, podle kterého je pravda dosažitelná výlučně prostřednictvím uplatnění čistého rozumu a jakékoliv „iracionální“ vlivy, které do procesu produkce poznání vstupují, mohou být toliko zdrojem omylu a nepravdy. ${ }^{9}$ Narušování akademické autonomie, a tedy i akademické svobody vnějšími - tj. politickými, ekonomickými, či jakýmikoliv „mimoakademickými“ - vlivy je tak podle tohoto argumentu ohrožením pravdy jako takové. Klasickým historickým příkladem uváděným na podporu tohoto argumentu je Lysenkova aféra v biologii, kde ideologické zásahy sovětského státního aparátu do vědeckého výzkumu měly za následek produkci nepravdivého poznání, jež bylo prezentováno jako pravdivé. Právě tímto příkladem argumentoval filosof Michael Polanyi v padesátých letech minulého století ve prospěch názoru, že akademická svoboda a nezávislost akademických institucí jsou nezbytným předpokladem toho, aby akademie mohla plnit svoji funkci, kterou je produkce a předávání pravdivého poznání, zatímco se zánikem akademické svobody současně zaniká i pravda, jelikož akademie tuto funkci není schopna nadále plnit (Polanyi 1951).

Přestože je však i v dostupných oficiálních a právních dokumentech akademická svoboda dodnes odůvodňována právě touto funkcí, ${ }^{10}$ ve světle poznatků nahromaděných v rámci společenských věd $\mathrm{v}$ průběhu druhé poloviny 20. století se toto zdůvodnění ukazuje jako poněkud nepřesvědčivé, a to $\mathrm{z}$ důvodu svého zakotvení v osvícenských pojmech racionality, objektivity a pravdy, jež jsou z jeho hlediska pojímány zcela neproblematicky. Racionalita, objektivita a pravda jsou z perspektivy tohoto argumentu nahlíženy jako primární účel akademické svobody, jelikož bez možnosti svobodného a nezaujatého kritického rozvoje objektivního poznání se otevírá prostor pro vznik nepravd (jež se za pravdu pouze vydávají) v rámci výzkumu a pro jejich následné šiření v rámci výuky. Slabina tohoto argumentu ovšem spočívá v tom, že tyto osvícenské koncepty byly přinejmenším během posledních padesáti let rozsáhle problematizovány a relativizovány. Množství studií rozpracovaných v rámci filosofie, sociologie nebo historie vědy

\footnotetext{
${ }^{9}$ Pro kritickou analýzu tohoto „asymetrického“ pojetí poznání viz zejména Barnes (1974) a Bloor (1976).

${ }^{10}$ Viz např. vymezení akademické svobody v Magna Charta evropských univerzit.
} 
poskytuje přesvědčivé základy pro argument, že představa „objektivní“ či „absolutní“ pravdy je neudržitelná a že „pravdivé“ poznání je vždy nevyhnutelně relativní ke konkrétnímu historickému a sociokulturnímu kontextu. ${ }^{11}$ Podobnému rozboru byly tyto koncepty podrobeny i v rámci kritické teorie, kde Theodor Adorno a Max Horkheimer ve své Dialektice osvícenství označují osvícenský projekt za masový podvod a poukazují na temporalitu poznání a na jeho závislost na konkrétním historickém a společenském kontextu (Adorno, Horkheimer 2009), a Herbert Marcuse později v Jednorozměrném člověku předkládá argument, že veškeré poznání je fakticky ideologií v tom smyslu, že kategorie objektivity a pravdy jsou toliko produktem a odrazem dominantních politicko-ekonomických podmínek a sil (Marcuse 1992). Ve světle těchto studií akademičtí pracovníci nemají jakkoliv privilegovaný přístup k pravdě a akademická praxe nemůže být nikdy z principu zcela autonomní a nezávislá na širším společenském kontextu. V rozporu s výše představeným racionalistickým ideálem je akademická činnost na základě aktuálních poznatků vždy nevyhnutelně formována a motivována i „mimoakademickými“ faktory, jež jsou tradičně označovány jako iracionální. Jestliže ale pravda není výsledkem nezaujaté, logicky a racionálně řízené činnosti, ale je ve skutečnosti sociálně konstruována a do procesu její produkce vstupují i politické, ekonomické a jiné iracionální faktory, požadavek akademické svobody za účelem zajištění akademické nezávislosti a možnosti nezaujatého hledání objektivní pravdy se v tomto ohledu ukazuje jako neobhajitelný, jelikož tento cíl je zkrátka a dobře nedosažitelný. Jinými slovy, dostupné společenskovědní poznatky vyvolávají otázku, proč poskytovat akademickým pracovníkům specifická práva za tím účelem, aby mohli nezaujatě přispívat k rozvoji objektivního poznání, když je ve skutečnosti představa objektivního poznání od základu pomýlená a akademičtí pracovníci z principu ničeho takového nikdy dosáhnout nemohou. Za takových okolností se požadavek akademické svobody jakožto politické nezaujatosti akademických institucí a jejich nezávislosti na politických, ekonomických a jiných externích vlivech ukazuje jako jen velmi obtížně udržitelný a obhajitelný.

Právě tyto nesnáze poskytly prostor pro alternativní výklad akademické svobody, který již neodkazuje k její epistemické funkci, nýbrž k funkci sociální. Jestliže totiž akademické instituce z principu nemohou být izolovány před externími vlivy, a akademická činnost je tak činností fundamentálně „politickou“, pak nedává dobrý smysl pokládat za jejich funkci produkci objektivního, pravdivého poznání, jelikož „objektivita“ i „pravda“ jsou z této perspektivy rovněž politickými kategoriemi. Jejich funkci je na základě této argumentační linie třeba hledat někde jinde, a to nikoliv v produkci a předávání hodnotově neutrálního poznání, ale v produkci a předávání takového poznání, které zosobňuje hodnoty, jež jsou společensky žádoucí a přínosné. ${ }^{12}$ Jinými slovy, tradiční chápání akademie jako slonovinové věže zosobňující osvícenské ideály racionality, objektivity a pravdy je třeba nahradit jejím alternativním pojetím, kde je její epistemická funkce v zájmu společnosti podřízena funkci politické. Z toho ovšem vyplývají závažné důsledky i pro výklad obsahu akademické svobody, jejíž tradiční chápání ve smyslu nezávislosti akademie na externích politicko-ekonomických vlivech nemá v kontextu tohoto alternativního pojetí akademie dobré opodstatnění. Jak v této souvislosti uvádí Richard Rorty (1994), akademická svoboda nemůže být $\mathrm{z}$ hlediska výše uvedených argumentů nikdy přesvědčivě odůvodněna s odkazem k osvícenským konceptům racionality, objektivity a pravdy - tedy epistemologicky -, ale její zdůvodnění je třeba hledat $\mathrm{v}$ její společenské či přesněji demokratické funkci - může být tedy odůvodněna jedině politicky s odkazem $\mathrm{k}$ demokratické funkci akademických institucí. Rorty

\footnotetext{
${ }^{11}$ Z filosofie vědy za všechny zmiňme Kuhn (1997) a Feyerabend (2001); z historie a sociologie vědy se pak jednalo zejména o Barnes (1974); Bloor (1976); Collins (1985); Latour, Woolgar (1986); Longino (1990); Shapin, Schaffer (1985); Shapin (1994) a další.

${ }^{12}$ To přitom ve světle prací uvedených v předchozí poznámce v principu platí jak pro oblast humanitních a společenských věd, tak i pro oblast věd přírodních, jakkoliv se přírodní vědy mohou jevit jako „apolitické“ a hodnotově neutrální.
} 
tímto v žádném ohledu nechce zpochybňovat epistemickou funkci akademie - tedy její funkci jakožto producenta a nositele poznání -, nicméně tuto funkci nahlíží na pozadí širšího společenského významu akademických institucí. Ty totiž nevykonávaly svoji činnost v izolaci před okolní společností, ale od samého svého vzniku naopak sehrávaly roli klíčové společenské protiváhy proti politickým a církevním autoritám a obecně proti autoritářství jakéhokoliv druhu, a jsou v tomto ohledu v prvé řadě ztělesněním osvícenských ideálů emancipace, společenského pokroku a demokracie. Tomu je pak třeba adekvátně přizpo̊sobit i výklad vlastního obsahu akademické svobody. Jestliže má akademická svoboda představovat soubor profesionálních výsad akademických pracovníků, jež mají garantovat jejich schopnost s plnou integritou se podílet na náplni této společenské funkce akademie, pak se jako logický jeví její výklad nikoliv ve smyslu zajištění ochrany akademické profese před politickými vlivy - to je ve světle výše uvedených argumentů nejen naivní, ale ignorování politického rozměru akademické činnosti se především jeví jako společensky nezodpovědné, nebot otevírá prostor pro šíření potenciálně antidemokratických idejí a tendencí -, ale ve smyslu zajištění možnosti akademických pracovníků angažovat se v rámci výkonu své profese právě za ty hodnoty, které jsou společensky žádoucí, tedy za hodnoty demokratické (Barendt 2010: 54-56).

Jelikož se s uplatněním tohoto „politizovaného“ pojetí akademické svobody lze setkat v řadě aktuálních i nedávných kauz, v nichž pojem akademické svobody sehrává ústřední roli, v následujícím oddílu bude toto pojetí podrobněji představeno na př́íladu jedné z nich. Bude takto možno lépe nahlédnout nejen konkrétní motivy, které vedou k jeho upřednostnění před tradičním pojetím akademické svobody, ale také některé praktické důsledky, které z něj vyplývají jak pro úvahy o akademické praxi a smyslu akademické profese, tak pro úvahy o funkci a společenském významu akademie jako takové.

\section{Akademie jako politika: „rozšî̃ené“ pojetí akademické svobody}

S výkladem akademické svobody jako souboru nikoliv čistě akademických, ale především politických výsad akademických pracovníků se lze v asi nejucelenější a nejvíce teoreticky propracované podobě setkat v textech Judith Butlerové. Butlerová představuje jednu z dlouhodobě klíčových postav mezinárodní debaty o akademické svobodě, a to přinejmenším od roku 2006, kdy se do této diskuse zapojila v souvislosti s kauzou akademického bojkotu izraelských univerzit z důvodu protestu proti izraelské okupaci palestinského území na Západním břehu Jordánu a v Pásmu Gazy (Butler 2006: 12). Právě tato kauza vedla k dosud asi vůbec nejrozsáhlejší debatě ohledně obsahu a smyslu akademické svobody a dodnes ji lze pokládat za pomyslný lakmusový papírek, na němž lze názorně demonstrovat rozdílné způsoby, jakými lze k pojmu akademické svobody přistupovat, i podstatné důsledky, které z konkrétních takových přístupů vyplývají.

Počátek této kauzy, která je podrobně zdokumentována v řadě publikací (viz např. Bilgrami, Cole 2015; Drummond 2013; Pappe 2010), lze datovat do roku 2004, kdy byla skupinou palestinských akademických pracovníků spuštěna „Palestinská kampaň za akademický a kulturní bojkot Izraele“ (v angličtině „Palestinian Campaign for the Academic and Cultural Boycott of Israel“, dále zkráceně jako PACBI) v rámci širšího palestinského politického hnutí „Bojkot, dezinvestice a sankce“ (v angličtině „Boycott, Divestment and Sanctions“, dále zkráceně jako BDS) založeného v reakci na porušování mezinárodního práva ze strany Izraele v podobě izraelské okupace palestinského území. ${ }^{13}$ Záměrem PACBI bylo poskytnout platformu pro nenásilný protest proti izraelské okupaci ve snaze přimět Izrael prostřednictvím nátlaku na jeho akademické instituce ukončit okupaci a respektovat mezinárodní právo. Jak je uvedeno v prohlášení kampaně,

\footnotetext{
${ }^{13}$ Viz https://bdsmovement.net/pacbi. Pro historickou přesnost je zde potřeba uvést, že hnutí BDS bylo založeno až v roce 2005 , tedy o rok později než PACBI; to se nicméně poté stalo jeho součástí.
} 
obsahem bojkotu mělo být konkrétně odmítání jakékoliv spolupráce s izraelskými akademickými institucemi, pozastavení jakéhokoliv financování izraelských akademických institucí a podpora palestinských akademických institucí nezávisle na těch izraelských, a to za účelem vyvinutí nátlaku na izraelskou vládu a vynucení ukončení vojenských operací na palestinském území, jakož i ukončení rasové segregace palestinských obyvatel. Tento bojkot se přitom neměl týkat všech izraelských akademických institucí bez rozdílu, ale pouze těch, které

a) se aktivně nestavějí na odpor proti diskriminaci nežidovských obyvatel na území Izraele;

b) se aktivně nestavějí na odpor proti izraelské okupaci Západního břehu Jordánu, jež je porušením mezinárodního práva;

c) aktivně nepodporují práva palestinských uprchlíků na návrat a kompenzaci za své ilegálně zkonfiskované domy a majetek (Butler 2015: 294).

Jinak řečeno, měl se tedy týkat pouze těch izraelských akademických institucí, které v reakci na izraelskou okupaci odmítají určitým zpo̊sobem politicky jednat na podporu utlačovaných palestinských obyvatel.

Nejen selektivní povaha bojkotu, spočívající v odpírání akademických práv na základě politických postojů, ale i sama idea záměrného odmítání spolupráce s několika vybranými univerzitami z politických důvodů (jednalo se konkrétně o Haifskou univerzitu a Bar-Ilanovu univerzitu; Butler 2006: 8) měly za následek vznik rozsáhlé diskuse ohledně oprávněnosti bojkotu, v jejímž rámci sehrával ústřední roli právě pojem akademické svobody. Podle řady komentátorů, mezi něž patří např. Joanna Williamsová, představuje bojkot jako takový zásah do akademické svobody, jelikož prosazuje záměrné znemožnění akademické spolupráce izraelských univerzit s jinými akademickými institucemi, a to čistě na základě politických motivů; dochází zde tedy k prokazatelnému omezování akademické svobody prostřednictvím narušení politické autonomie a pronikání politických vlivů do akademického rozhodování, jež má být na těchto vlivech naopak nezávislé (viz Williams 2016: 11-12, 176-180). Jiní komentátoři - mezi něž patří právě i Butlerová - ovšem naopak pokládají bojkot za zcela legitimní (ba přímo jedinou správnou) reakci na vojensko-politické intervence Izraele na palestinském území a s nimi spojenou pasivitu izraelských akademických institucí; jako takový tedy není útokem na akademickou svobodu, ale je právě naopak aktem na její obranu - jelikož je to ve skutečnosti palestinská akademická svoboda, která je izraelskou okupací nejen ohrožována, ale i fakticky decimována jako první.

Východiskem tohoto postoje Judith Butlerové k bojkotu izraelských univerzit je to, co sama pojmenovává jako „podmíněnou“ povahu akademické svobody. Akademická svoboda je podle Butlerové souborem práv, který je podminěný (conditioned), čímž má na mysli, že mưže být v praxi realizována pouze tehdy, když jsou splněny určité institucionální či společenské podmínky (Butler 2015: 293). Butlerová svo̊j způsob chápání akademické svobody jinými slovy vysvětluje ještě tak, že akademická svoboda by neměla být nahlížena toliko jako soubor abstraktních práv, ale spíše jako soubor materiálních práv v tom smyslu, že zahrnuje a současně vyžaduje specifickou funkční materiální infrastrukturu garantující základní občanská práva a (neakademické) svobody (Butler 2006: 11). Akademická svoboda tak podle Butlerové nezahrnuje toliko svobodu výzkumu a výuky (a případně další práva zmiňovaná v rozličných dostupných deklaracích akademické svobody), ale zahrnuje také například svobodu pohybu, právo na vzdělání, svobodu slova a další fundamentální lidská práva, bez nichž akademickou svobodu ve výše uvedeném „abstraktním“ smyslu nelze vůbec uvažovat. Jak uvádí právě na prŕíkladu izraelské okupace palestinského území, tato okupace de facto nezasahuje do akademických svobod palestinských akademických pracovníků ve výše uvedeném abstraktním smyslu - tyto svobody nejsou okupací nijak napadány ani explicitně omezovány -, ale tato okupace zcela jednoznačně destruktivním zpơsobem zasahuje do 
palestinské institucionální (tj. materiální) infrastruktury, v důsledku čehož je podstatným způsobem narušováno financování palestinských akademických institucí, dále je rovněž do značné míry omezován pohyb palestinských akademických pracovníků (i studentů), a tedy i dostupnost jejich pracovišt atd. (Butler 2006: 16). Podle Butlerové za takových okolností neexistuje žádný dobrý důvod, proč by akademické svobody palestinských akademiků - ačkoliv tedy nejsou napadány či ohrožovány př́mo - neměly být pokládány za závažně porušené a proč by za bezprecedentní útok na akademickou svobodu neměla být v první řadě označena právě izraelská okupace, a nikoliv bojkot, který je až odpovědí na ni (Butler 2015: 295). Jak sama uvádí, „[j] estliže existuji určité podminky, bez nichž [akademická svoboda] nemůže být realizována, pak museji být tyto podmínky chápány jako nedílná součást práv [spadajících pod akademickou svobodu] jako takových" (Butler 2015: 293); a jak píše na jiném místě, „[s] ystematické podkopávání palestinských vysokoškolských instituci je útokem na akademickou svobodu stejně tak jako na ideály demokracie, s nimiž je akademická svoboda inherentně spojena" (Butler 2006: 17). Skutečně autentická, a nikoliv jen pokrytecká péče o akademickou svobodu proto dle jejího názoru musí nezbytně zahrnovat i péči o tyto obecnější institucionální či společenské podmínky, tj. o dodržování fundamentálních lidských práv a o demokratické principy solidarity, rovnosti a úcty k člověku. Tyto podmínky tudíž nejsou něčím, co by bylo z hlediska akademické profese irelevantní a co by v protikladu k akademickým záležitostem mělo být odsunuto do oblasti politiky, ale hranice mezi akademií na jedné straně a politikou na straně druhé se na pozadí nezbytnosti těchto podmínek pro fungování akademie v pojetí Butlerové naopak stírají:

Akademická svoboda je závislá na demokratických veřejných institucích zavazujících se k dodržování principu nezasahování státu, náboženských autorit a korporátních sil do produkce a rozšiřování vědění. Boj za akademickou svobodu je tudíž součástí boje za demokracii. Akademická svoboda náleží univerzitám, avšak univerzity náležejí ke konkrétním lokalitám a př́slušným lokálním praktikám. Jejich zdi jsou daleko více propustné, než jak vypadají na základě právních rozlišení (Butler 2018).

Tradiční pojetí akademie jako autonomní instituce, jejíž činnost je nezávislá na externích politických vlivech - anebo před těmito vlivy může být přinejmenším chráněna - je tak podle Butlerové značně zavádějící, nebot případ palestinského bojkotu jasně ukazuje, že akademii od těchto širších společenských podmínek oddělit jednoduše nelze a že její schopnost podílet se s plnou integritou na výzkumné a pedagogické činnosti je s těmito podmínkami inherentně propojena. Z toho vyvozuje závěr, že nedílnou součástí profesionální odpovědnosti akademických pracovníků musí být nejen ona výzkumná a pedagogická činnost - tedy činnost epistemická -, ale právě také aktivní péče o zachování takových politických podmínek, bez nichž by plnohodnotný výkon této epistemické činnosti nebyl možný - tedy činnost politická. Jestliže akademické instituce nemohou podle Butlerové plně vykonávat svoji epistemickou funkci v jiných než demokratických podmínkách, pak primárním úkolem akademických institucí podle Butlerové nemůže být produkce a předávání vědění bez ohledu na okolní svět, ale úsilí o prohlubování, rozšiřování a kultivaci sociálně spravedlivé, ${ }^{14}$ demokratické společnosti. Akademické instituce jsou tak podle Butlerové na tomto základě institucemi v pravém slova smyslu politickými. Jako takové by neměly přistupovat k výzkumu a výuce bez ohledu na širší společenské okolnosti, ale akademičtí pracovníci mají v rámci výkonu svých badatelských a pedagogických akademických aktivit povinnost prosazovat principy svobody a spravedlnosti, solidarity a úcty k člověku a společně se podílet na rozvoji materiální a morální pomoci na mezinárodní úrovni. V této souvislosti Butlerová doslova uvádí,

\footnotetext{
${ }^{14}$ Zde je třeba podotknout, že koncept sociální spravedlnosti může být vykládán mnoha odlišnými, někdy i zcela protichůdnými způsoby (viz Heywood 2005: 251-259). Butlerová sama svoje chápání tohoto pojmu ve svých textech explicitně nevymezuje, nicméně z kontextu je patrné přinejmenším to, že k němu přistupuje z liberálně-levicové politické perspektivy.
} 
že pokud akademická instituce selhává v plnění této své politické role, pak ztrácí nárok na své místo v rámci akademie jako takové, jelikož neplní svoji povinnost vůči společnosti (Butler 2017: 859). ${ }^{15}$ Úkolem akademických institucí podle Butlerové přitom není toliko vyučovat a provádět výzkum o formách solidarity, jež posilují vyhlídky na svobodný, spravedlivý a důstojný svět, ale jít $\mathrm{v}$ této věci př́kladem a aktivně prosazovat tyto principy skrze vzájemnou spolupráci na mezinárodní úrovni. Smyslem akademické svobody stejně tak není toliko umožnit akademickým pracovníkům podílet se na svobodném výzkumu a vzdělávání, ale především umožnit jim objasňovat a prosazovat principy života založeného na ideálech spravedlnosti, důstojnosti a rovnosti. Akademické instituce mají v rámci své činnosti tedy nejen artikulovat, ale především aktivně prosazovat a bránit myšlenky a př́stupy, které posilují tyto demokratické principy ve společnosti, a mají tak činit jakožto univerzity, tedy v rámci své akademické odpovědnosti. Podle Butlerové se nejedná o pouhý etický a společenský závazek, ale jedná se o fundamentální povinnost univerzity a akademie jako takové (Butler 2017: 859).

K této roli, kterou mají akademické instituce plnit, je ovšem podle Butlerové nezbytné odpovídajícím způsobem přizpůsobit i výklad vlastního obsahu akademické svobody, jehož omezení toliko na výzkumnou, pedagogickou a př́ípadně jinou tradičně akademickou činnost (jako je např. samospráva akademických institucí) je pro tento účel nedostatečné. Aby akademičtí pracovníci mohli plnit svoji demokratickou povinnost, musí jim být garantován adekvátní soubor práv, který by jim plnění této povinnosti umožnil, a Butlerová proto na tomto základě požaduje prosazení „rozššřeného" pojetí akademické svobody, v němž tato svoboda nebude interpretována toliko jako svoboda výzkumu, výuky apod., ale jehož součástí bude právě i svoboda politické angažovanosti akademických pracovníků jakožto akademických pracovníků. Butlerová si v této souvislosti přitom velmi dobře uvědomuje konceptuální odlišnost akademické svobody od svobody slova (viz Butler 2018), avšak podle jejího názoru se však obě tyto svobody, ačkoliv jsou od sebe vzájemně odlišné, protínají právě v oblasti politického vyjadřování a politického aktivismu. V pozadí jejího pojetí akademické svobody a akademie jako takové se nachází přesvědčení, že stejně jako je jedním ze základních pilírư demokratické společnosti právo občanů kritizovat vládnoucí autority, zpochybňovat dominantní společenská přesvědčení a vymezovat se proti názorům většiny, mělo by být i akademikům v rámci akademické svobody garantováno právo svobodného politického vystupování a jednání, jakkoliv je takové jednání rozporuplné, provokativní, politicky nežádoucí, či jak uvádí sama Butlerová - „agonistické“ (Butler 2018). Jestliže má akademie plnit svoji výše zmíněnou demokratickou společenskou roli, garance takové politické svobody, která akademikovi poskytuje právo na „disent“ v rámci daného politického, společenského a institucionálního kontextu, je pro tento účel zcela nezbytná. Jakékoliv politické omezení akademických pravomocí naopak otevírá prostor pro nekontrolované šíření antidemokratických tendencí ve společnosti, a tedy i pro ohrožení akademie samé. Butlerová k tomu doslova uvádí:

Tím, že budeme trvat na svobodě myšlení, vyjadřujeme podporu tem, kdo by chtěli zpochybňovat legitimitu nespravedlivých politických forem - včetně politické struktury univerzity samé, když se zaprodává korporátním zájmům nebo státní moci. Vyjadřujeme podporu těm, kdo protestují proti rasismu, misogynii a vykořistování pracujících; těm, kdo kriticky přemýšlejí o autoritě, moci a násilí; těm, kdo bojují za sjednocení akademických pracovníků; těm, kdo odmítají ratifikovat státní ideologie (Butler 2018).

\footnotetext{
${ }^{15} \mathrm{Na}$ tomto základě se pak jako zcela pochopitelný ostatně jeví právě i postoj Butlerové k bojkotu izraelských akademických institucí. Ty totiž svojí netečností vůči izraelské okupaci palestinského území selhávají v plnění své výše zmíněné politické role, a jejich bojkot je tak z této perspektivy zcela legitimní, jelikož v důsledku tohoto svého selhání ztrácejí své právoplatné místo mezi ostatními akademickými institucemi.
} 
Jak v této souvislosti podotýká Stanley Fish (2014), akademická svoboda v pojetí Butlerové je de facto neomezenou svobodou kritiky podřízené demokratickým politickým zájmům a s nimi spojeným ideálům solidarity, rovnosti a sociální spravedlnosti. Je právem na disent, jehož rozsah přesahuje etablované institucionální normy akademie i společnosti jako takové. Pokud by totiž akademická svoboda povolovala pouze některé formy disentu, zatímco jiné by zakazovala, akademie by již nemohla v plném rozsahu plnit svoji demokratickou společenskou funkci, a namísto nástroje společenského pokroku by se mohla stát nástrojem k obhajobě a zachování jakkoliv nežádoucího či problematického stávajícího politického statu quo (Fish 2014: 69-70).

Butlerová na podporu svého „rozšířeného“ pojetí akademie a akademické svobody uvádí vedle bojkotu izraelských univerzit ještě řadu dalších kauz z posledních několika let, kdy byli akademičtí pracovníci zbaveni (nejen) své akademické svobody a vystaveni řadě dalších postihů právě z důvodu politické angažovanosti ve prospěch solidarity a sociální spravedlnosti. Jednou z posledních takových velkých kauz je petice tureckých akademických pracovníků požadující mírové ukončení tureckých vojenských operací v kurdském regionu. Jedná se o petici „Academics for Peace" z roku 2016, kterou podepsalo více než 1100 tureckých akademiků a kterou současně podpořilo i více než 5000 členů široké veřejnosti. Z rozhodnutí tureckého prezidenta Recepa Tayyipa Erdoğana bylo v reakci na tuto petici zbaveno svých pozic více než 5000 tureckých akademických pracovníků a celkem patnáct tureckých univerzit bylo uzavřeno. Propuštěným akademikům bylo současně v podstatě znemožněno pokračování v akademické činnosti, jelikož byly rovněž anulovány jejich cestovní doklady, v důsledku čehož je pro ně nemožné z Turecka vycestovat a hledat práci na univerzitách v jiných zemích. Podle Butlerové je politický útok ze strany Erdoğanovy vlády na turecké akademické pracovníky útokem proti akademii jako takové, jelikož angažovanost ve jménu míru, solidarity a sociální spravedlnosti je dle jejího názoru fundamentální povinností akademických institucí ( $\mathrm{z}$ důvodů, jež byly uvedeny výše), a jako taková by tudíž měla být chráněna právě akademickou svobodou. Reakce na akademickou mírovou petici je tak podle ní přímým útokem na akademickou - nikoliv politickou - svobodu tureckých akademiků, a tedy i útokem na nezávislost akademie a snahou o podkopání její společenské role. Stejně jako v př́ípadě bojkotu izraelských univerzit je dle jejího názoru i zde povinností akademických institucí na celém světě vyjádřit podporu a poskytnout pomoc postiženým tureckým akademikiom, a to nejen prostřednictvím šíření povědomí o této kauze, ale především prostřednictvím veřejné politické angažovanosti za práva těchto akademiků a na obranu jejich porušené akademické svobody (Butler 2017: 860; Butler 2018; Butler, Ertür 2017).

Akademická svoboda je tedy v pojetí Butlerové chápána nikoliv v tradičním „úzkém“ významu jako svoboda akademických institucí i jejich pracovníků nezaujatě produkovat a předávat poznání, ale jako svoboda aktivně participovat na kultivaci a reprodukci demokratických politických hodnot, jejichž zachování je nezbytným předpokladem realizace akademické svobody v onom tradičním slova smyslu. Jestliže je primární náplní akademické profese epistemická činnost zahrnující produkci a transfer vědění v rámci výzkumu a výuky, pak akademickou svobodu v pojetí Butlerové nelze označit toliko za profesionální svobodu vázanou výlučně na výkon těchto epistemických aktivit, ale je daleko spíše svobodou politickou, která akademické pracovníky opravňuje - a současně zavazuje - k politické angažovanosti v zájmu demokracie a sociální spravedlnosti, tedy k činnosti dalece přesahující tradičně pojímanou náplň akademické profese. Pokud by si v jejím pojetí měla akademická svoboda zachovat svůj profesionální status, pak je potřeba nahradit ono tradiční chápání úkolu akademických institucí rozšířeným pojetím akademie, které pokládá za náplň akademické profese nikoliv pouze produkci a předávání vědění bez ohledu na širší společenské souvislosti, ale primárně právě starost a péči o tyto souvislosti a snahu o kultivaci demokratických politických ideálů. Jejím argumentem ve prospěch tohoto pojetí akademické svobody, resp. pro jeho upřednostnění před tradičním apolitickým pojetím, je přitom 
předpoklad - v jehož prospěch čelí množství historických příkladů -, že akademické instituce mohou plnit svoji funkci pouze v těchto demokratických podmínkách, a péče o akademickou svobodu (a jejím prostřednictvím i o akademii jako takovou) tak proto musí zahrnovat i soustavnou aktivní kultivaci takového nezbytného politického, společenského a institucionálního rámce. Ignorování tohoto širšího společenského kontextu a vykonávání akademické práce bez ohledu na její společenské souvislosti naopak představují nezodpovědný prrístup k akademické profesi - nezodpovědný proto, jelikož otevírá prostor pro šiření antidemokratických tendencí ve společnosti, a tím i pro možné ohrožení integrity akademie jako takové. Proto pokud má akademie trvale plnit svoji roli, musí být podle Butlerové politicky uvědomělá; avšak aby mohla být politicky uvědomělá, musí být akademickým pracovníkům v rámci výkonu jejich profese - tedy nikoliv pouze jakožto běžným občanům - garantována odpovídající politická svoboda. Právě z těchto důvodů musí akademická svoboda podle Butlerové zahrnovat nejen svobodu výzkumu a výuky (a další tradičně zmiňovaná práva), ale také právo politicky se angažovat ve jménu demokratických ideálů a hodnot.

\section{Akademická svoboda a hranice mezi akademií a politikou}

Na příkladu Butlerové a jejího hodnocení nedávných kauz, jež podnítily diskusi ohledně obsahu a smyslu akademické svobody, se velice názorně ukazují teoretické i praktické důvody, na jejichž základě se tradiční osvícenské pojetí akademické svobody může ukazovat jako zastaralé, naivní a neschopné ochránit individuální akademické pracovníky ani integritu akademie jako takové. Redefinování akademické svobody jako svobody politické - jakož i odpovídající přehodnocení významu akademické profese a akademie jako takové - se tak ve světle těchto důvodů může jevit jako přesvědčivé i žádoucí nejen z morálního hlediska, ale také z hlediska teoretického. Domnívám se ale, že navzdory tomu je třeba k němu přistupovat neméně opatrně a se stejným podezřením, jako k tradičnímu osvícenskému pojetí akademické svobody a akademie, vưči němuž se takto přesvědčivě vymezuje. Jeho praktické dopady na akademickou profesi a její společenský význam se totiž při bližším pohledu ukazují jako přinejmenším stejně tak nebezpečné, jako je prosté ignorování politicko-ekonomického rozměru akademické práce a lpění na osvícenských ideálech racionality, objektivity a pravdy, jejichž nekritické přijímání se ve světle stávajících společenskovědních poznatků ukazuje jako jen stěží udržitelné.

Slabé místo politizovaného pojetí akademické svobody se nachází v jeho samotných základech, které se staví proti tradičnímu rozlišení (politicky neutrální) akademie na jedné straně a politiky na straně druhé. Právě setření této vzájemné hranice s sebou ale pro akademickou praxi nese značně problematické důsledky. Na jednu stranu se sice zdá být žádoucí - ba nevyhnutelné - souhlasit s tím, že akademická praxe vskutku je „pokračováním politiky odlišnými prostředky" (Latour 1988: 229) a že představa „apolitické“ akademie je pozůstatkem starých osvícenských ideálů, které již byly nenávratně překonány. Současně by ale bylo vážnou chybou ztratit ze zřetele některé podstatné rozdíly, které tyto dvě oblasti navzdory některým jejich společným rysům fundamentálně odlišují. Jestliže se totiž akademická činnost ve světle dostupných analýz ukazuje jako de facto politická činnost, neznamená to ještě, že má být jako politická činnost také vykonávána, a že by tedy ze vzájemných podobností v deskriptivní rovině měly být vyvozeny normativní důsledky pro akademickou praxi. Právě toho se ale politizované pojetí akademické svobody dopouští. Jak bylo uvedeno výše na př́́kladu Butlerové, toto pojetí stojí na předpokladu, že vzhledem k tomu, že racionalita, objektivita a pravda jsou politickými kategoriemi, akademickou činnost je třeba uvědoměle podřídit politickým zájmům, a to za tím účelem, aby přispívala $\mathrm{k}$ reprodukci žádoucích politických ideálů a hodnot ve společnosti. Pokud by přitom podřízení této epistemické role akademie politickým zájmům v podobě explicitního zahrnutí politických faktorů do akademického rozhodování vyvolávalo obavy z narušení objektivity produkovaného poznání 
a z deformace pravdy ve prospěch politické ideologie, jak vůči němu namítá např. Williamsová (2016), nabízela by se logická odpověd, že ideál objektivní pravdy je v praxi nedosažitelný a že tím nejlepším (a současně společensky nejzodpovědnějším), co můžeme udělat, je zkrátka a dobře upřednostňovat ty „pravdy“, které jsou pro společnost nejvíce prospěšné. Toto pojetí ale opomíjí podstatnou skutečnost, že ačkoliv je tento ideál v praxi nedosažitelný, v kontextu akademie plní klíčovou roli právě jakožto ideál, tedy roli normativní. Jak uvádějí Harry Collins a Robert Evans (2017), ideál objektivní pravdy je jednou z tzv. formativních aspirací, které definují akademickou formu života a které ji odlišují od forem ostatních, včetně té politické. Akademická činnost se podle nich vyznačuje mj. právě tím, že navzdory relativizaci pojmů racionality, objektivity a pravdy je vykonávána zkrátka a dobře tak, jako by tyto pojmy relativizovány nebyly a jako by objektivní pravda v praxi dosažitelná byla. Právě tato aspirace na dosažení objektivní pravdy - bez ohledu na to, že to v praxi stricto sensu není možné - je tím, v čem je akademická činnost v pravém slova smyslu „akademická“ (Collins, Evans 2017: 40).

Normativní význam těchto ideálo̊ pro akademii a její schopnost plnit svoji funkci se plně vyjevuje při představě akademie, která by na tyto ideály otevřeně rezignovala a která by namísto nich fakticky podřizovala svoji činnost ideálům politickým, jak je požadováno v rámci „rozšířeného“ pojetí akademické svobody. Kromě množství historických př́kladů, které velice přesvědčivě dokládají patologické důsledky podřízení akademického rozhodování politickým zájmům v nedemokratických režimech, není nikterak obtížné nahlédnout i potenciálně nebezpečné důsledky podřízení akademické činnosti zájmům demokratickým, jež požaduje Butlerová. I za takových okolností je zde totiž možno spatřovat možnou hrozbu „umlčování" názorů a hlasů těch akademiků, kteří nesdílejí liberálně-demokratické politické přesvědčení, tj. názorů a hlasů, jež jsou jakkoliv v rozporu se zmíněnými ideály solidarity, rovnosti a sociální spravedlnosti, ačkoliv přitom splňují relevantní epistemologická kritéria. Akademické rozhodování by za takových okolností v podstatě získalo povahu politického rozhodování - jak v oblasti výzkumu, tak i v oblasti výuky -, a akademie by prošla transformací z místa definovaného úsilím o produkci a transfer nezaujatého poznání na místo nerozlišitelné od reálné politiky, tedy na místo vzájemného soupeření politických ideologií namísto objektivních epistemologických kvalit (bez ohledu na faktickou problematičnost pojmů objektivity, pravdy apod.). Zachování akademie v její stávající podobě naopak nezbytně předpokládá i současné zachování normativní hranice mezi akademií na jedné straně a politikou na straně druhé, at už mají jakékoliv společné rysy v rovině deskriptivní. Tomu by měl adekvátně odpovídat i výklad obsahu akademické svobody, která se jakožto svoboda profesionální vztahuje výlučně k profesionální funkci akademických institucí, a není tedy důvod, aby vedle profesionálních odpovědností akademických pracovníků pokrývala i jakoukoliv jejich odpovědnost politickou.

Jako extrémní př́íklad důsledků, které může mít setření hranice mezi akademií a politikou a podřízení akademické profese politickým zájmům - je ostatně možné uvést relativně nedávný případ dnes již bývalého kanadského profesora fyziky Denise Rancourta související s jeho praktikováním tzv. akademického squattingu (Fish 2014: 105; 2015: 278). Tímto označením bylo pojmenováno Rancourtovo nahrazování standardního obsahu jím vyučovaných předmětů - konkrétně se jednalo o kurz environmentální fyziky - výukou politického aktivismu. Jak uvádí Fish, Rancourt v rámci výkonu svých pedagogických povinností „okupoval“ prostor standardních vyučovaných předmětů a tyto předměty přetvářel v kurzy politického aktivismu, a to nikoliv ve smyslu přednášek $o$ politickém aktivismu, ale ve smyslu přednášek o tom, jak se stát a být politickým aktivistou (Fish 2014: 105). Praxi „akademického squattingu“ přitom Rancourt obhajoval jako zcela legitimní a potřebnou, a to na základě argumentu, že současné univerzity jsou ve skutečnosti diktaturami, v jejichž čelech stojí samozvaní manažeři ve službách neoliberálních kapitalistických zájmů, a standardní univerzitní výuka fakticky neslouží k žádnému jinému účelu než $\mathrm{k}$ indoktrinaci studentů a $\mathrm{k}$ jejich přeměně $\mathrm{v}$ poslušné zaměstnance $\mathrm{v}$ kapitalistickém sys- 
tému ve jménu „ideologie služebnictví“ (Fish 2014: 105). Právě na Rancourtově příkladu se názorně ukazují problematické důsledky stírání hranic mezi akademií a politikou, po němž - byt ve jménu vznešených a společensky žádoucích ideálů - volá v rámci svého „rozšířeného“ výkladu akademické svobody Butlerová. I Rancourt argumentuje ve prospěch akademického squattingu v termínech jeho opozice proti „zlým“ kapitalistickým zájmům a legitimitu pro svoji činnost nachází právě v pojmu akademické svobody, který chápe jako garanci naprosté svobody akademických pracovníků (i studentů) v přístupu k náplni jejich akademických povinností. Pouze tehdy, když akademický pracovník není omezován ve své činnosti ani politickými strukturami, ani samými institucionálními normami akademie, může skutečně odpovědně plnit svoji profesionální roli spočívající v důsledné kritice za účelem rozvoje rovnější a spravedlivější společnosti. Jakýkoliv jiný stav, kdy je akademický pracovník ve své činnosti omezován politickými či jinými tlaky zvenčí nebo institucionálními akademickými normami zevnitř akademie, je dle Rancourtova názoru stavem ohrožení akademické svobody, kdy akademickým institucím hrozí riziko, že se z nástrojů společenského pokroku promění v nástroje ve službách vládnoucích politických či ekonomických autorit - nástroje, jejichž fundamentální funkcí není kritika, ale konzervativní obhajoba a legitimizace stávajícího politicko-ekonomického statu quo.

Má však akademická svoboda opravňovat akademiky k takovéto politicky motivované činnosti? Zcela jistě nikoliv, nebot aktivity, jako je např. akademický squatting, přestože mohou být motivovány dobrými důvody a mohou se jevit jako politicky žádoucí, jsou v prŕíkrém rozporu s tím, co je fundamentálním obsahem akademické profese a zač akademik nese profesionální odpovědnost. S akademickou činností zkrátka a dobře nemají zhola nic společného. Akademická svoboda je zde fakticky zaměňována za svobodu politickou a setřením hranice mezi akademií a politikou a podřízením akademické činnosti politickým zájmům - jsou zde z akademie vytlačovány zájmy v pravém slova smyslu akademické, tj. ty, jež akademickou činnost definují jako akademickou a které akademii od politiky zásadním způsobem odlišují, jako jsou např. právě snaha o nezaujatý, tj. politicky zcela nestranný rozvoj objektivního poznání a předávání takového poznání v rámci výuky. Ačkoliv byla faktická realizovatelnost takových snah v průběhu přinejmenším posledních padesáti let značně narušena problematizováním pojmů objektivity a pravdy, jakož i nabouráním představ o apolitičnosti a nezaujatosti akademické praxe, naprostá rezignace na tyto snahy a podřízení akademické profese politickým zájmům de facto smazává jakékoliv rozdíly mezi akademickou a politickou kulturou, mezi světy akademické praxe a reálné politiky, a mezi akademickým a politickým rozhodováním. Přijetí, implementace a praktická realizace takového „politizovaného“ pojetí akademie a akademické svobody, jakkoliv by byla míněna v zájmu sociálně př́nosných ideálů, by pak vystavovala akademii hrozbě, že bude postupně transformována v něco docela jiného než nástroj nezaujaté produkce a předávání objektivního poznání, kterým byla - nebo se alespoň snažila být - od svého vzniku dodnes.

To neznamená, že by teoretická východiska, na nichž rozšířené pojetí akademické svobody spočívá, měla být zkrátka a dobře ignorována. Jestliže však nemá být stávající povaha akademie a její funkce ohrožena tím, že bude explicitně politizována, je třeba z těchto teoretických poznatků vyvodit pro naše chápání akademické svobody odlišné důsledky, než jaké z nich vyvozuje např. Butlerová. Podle mého názoru „rozšîřené“ pojetí akademické svobody selhává z toho důvodu, že si jako své východisko klade otázku, jaká akademie fakticky je, a z této otázky pak vyvozuje normativní závěry ohledně toho, jaká by akademie být měla. Jak bylo ovšem ukázáno výše, výsledkem je radikální proměna normativní struktury akademie se závažnými dopady na akademickou praxi i na celkovou funkci, kterou akademické instituce mají a mohou ve společnosti plnit. Představa, že by součástí profesionální odpovědnosti akademika mělo být prosazování liberálně-demokratických (nebo jakýchkoliv jiných) politických hodnot, tj. že by akademická profese měla být politicky angažovaná, je fundamentálně neslučitelná s pojetím akademie jako místa nezaujatého a politicky 
neutrálního rozvoje poznání, a přetváří tak akademii z instituce usilující o politickou nezávislost na instituci explicitně politickou. Výklad akademické svobody jako souboru práv, mezi něž patří i právo akademika porušovat etablované akademické institucionální standardy a normy pod politickými pohnutkami, v tomto ohledu nemá se stávajícím profesionálním obsahem akademického povolání nic společného. Setrvávání u tradičního osvícenského pojetí akademické svobody se nicméně rovněž ukazuje jako neudržitelné, byt z jiných důvodů. Východiskem tradičního pojetí akademické svobody opírajícího se o osvícenské ideály racionality, objektivity a pravdy sice je normativní rovina akademie, a nikoliv její faktická povaha na úrovni deskriptivní, ovšem jeho klíčovým nedostatkem je přesvědčení, že normativní představa politicky neutrální a nezaujaté akademie produkující objektivní poznání je také realizovatelná v praxi. Akademická svoboda je proto z pohledu tohoto pojetí vykládána jako právo na faktickou apolitičnost akademické profese a její ochranu před jakýmikoliv mimoakademickými externími vlivy, které narušují nezaujatost akademické činnosti a kompromitují takto její výsledky. Jak bylo ale ukázáno výše, takové pojetí akademie je v praxi neudržitelné, jelikož akademickou činnost nelze oddělit od širšího společenského kontextu, v němž je vykonávána, a jako taková je politickými, ekonomickými a jinými vnějšími vlivy nevyhnutelně prostoupena, aniž by tím přitom byla nezbytně jakkoliv ohrožována. Výklad akademické svobody jako práva na ochranu před těmito vlivy tak sice nevede k radikální transformaci akademie, jako je tomu u „rozšřřeného“ pojetí akademické svobody, ale zkrátka a dobře nedává smysl, protože akademická svoboda je z jeho pohledu de facto ohrožována neustále, a to z podstaty akademie jako takové, nebot ta politicky neutrální v praxi nikdy být nemůže.

Jestliže má akademická svoboda sloužit mj. jako kritérium integrity akademie, které umožní jasně a jednoznačně odlišit př́ípady, kdy je tato integrita ohrožena a kdy naopak ohrožena není, je tudíž třeba k výkladu jejího obsahu přistoupit odlišným zpơsobem, a to takovým, který bude brát v potaz fundamentálně ,politickou“ povahu akademické činnosti, jako je tomu v případě „rozšířeného“ pojetí akademické svobody, ale přitom nebude opomíjet normativní rovinu akademické profese, jako je tomu u pojetí tradičního. Je tedy třeba hledat takový výklad akademické svobody, který bude akceptovat faktickou neoddělitelnost „akademického“ a „politického“, ale současně bude zachovávat ostrou hranici mezi těmito dvěma oblastmi na normativní úrovni. Dobrým východiskem pro rozvinutí takového výkladu akademické svobody je dle mého názoru právě takové pojetí vzájemného vztahu mezi akademií na jedné straně a politikou na straně druhé, o němž pojednává Max Weber ve své klasické přednášce „Věda jako povolání“. Weber zde na jednu stranu uznává neoddělitelnost politických záležitostí od záležitostí akademických, současně však poukazuje na to, že i přes tento fakt se odpovědný výkon akademického povolání musí vyznačovat snahou o maximální politickou a obecně hodnotovou neutralitu a nezaujatost, jakkoliv může takový cíl plnit toliko roli normativního ideálu. Nemožnost jeho realizace v praxi nikterak nesnižuje jeho fundamentální normativní funkci pro výkon akademické profese a pro společenskou roli akademie jako takové. Jak sám uvádí:

Ř́ká se, a já to podepisuji, že politika nepatř̌i do posluchárny. Nepatří tam ze strany studentů. [...] Politika ovšem nepatří do posluchárny ani ze strany docenta. A to zejména tehdy, když se politikou zabývá vědecky, v tom případě nejméně ze všeho. Nebot praktickopolitické stanovisko a vědecká analýza politických útvarů a stranických postojů jsou dvě různé věci. Když někdo mluví v parlamentu o demokracii, nijak neskrývá své osobní stanovisko: V̌̌dyt přece právě jasné zaujetí stranického stanoviska je zde jeho největší povinností i dluhem. Pronesená slova pak nejsou výrazem vědecké analýzy, nýbrž prostředky politické soutěže o stanoviska těch druhých. Nejsou to radlice, jež by měly kypřit půdu kontemplativního myšlení, nýbrž zbraně proti soupeři, tedy bojové prostředky. Bylo by pokrytectvím, kdyby se tímto způsobem hovořilo na přednášce nebo v posluchárně. Bude-li se zde např́klad mluvit o „demokracii“ 
a budou-li se vyzvedávat její různé formy, bude to analýza způsobu, jak demokracie funguje, a zjištění, jaké jednotlivé následky má její jedna nebo druhá forma pro životní podmínky. A pak to bude také konfrontace s jinými, nedemokratickými formami politického řádu a bude se jednat o pokus dospět tak daleko, aby byl posluchač sám schopen najít bod, z něhož k tomu může zaujmout postoj na základě svých posledních ideálů. Avšak opravdový učitel se přísně vystř́há toho, aby z katedry vnucoval nějaké stanovisko, at již slovy nebo sugescí, nebot to je přirozeně nejméně čestný způsob, aby se takzvaně „nechala mluvit fakta“ (Weber 1998: 122-123).

Weber v tomto úryvku na př́kladu univerzitní výuky poukazuje na fundamentální odlišnost akademické a politické praxe. Bez ohledu na to, nakolik do obsahu výuky - at už explicitně nebo implicitně - proniká politická problematika, profesionální akademický př́stup k výuce by měl aspirovat na její „akademičnost“ (v protikladu k „političnosti“) prostřednictvím prezentace daného tématu způsobem otevírajícím prostor k přemýšlení a diskusi, nikoliv způsobem sugestivním, který diskusi naopak uzavírá. ${ }^{16}$ Stanley Fish tento normativní princip pojmenovává jako tzv. akademizaci (academicizing), kterou charakterizuje následovně:

Imperativ akademizace říká, že když je v rámci výuky pojednáváno jakékoliv téma, mělo by být vyňato z reálného světa každodenní praxe - ze světa, kde se konají volby, provádějí politická rozhodnutí a organizují protesty -, a zasazeno do akademického kontextu, kde je struktura, význam, hodnota a historie tohoto tématu podrobena zkoumání za použití tradičních metod [...] humanitních, společenských a přírodních věd (Fish 2014: 31).

Imperativ akademizace, tedy určité aspirace na politickou a obecně hodnotovou neutralitu akademické profese, přitom není nutno omezovat pouze na oblast akademické výuky, ale lze jej chápat jako vůdčí normativní princip akademické činnosti jako takové. Z tohoto hlediska jej pak lze současně chápat také jako kritérium integrity akademické činnosti: odpovědný výkon akademické profese se vyznačuje snahou o naplnění tohoto principu, zatímco jeho porušení - např. v podobě podřízení akademického rozhodování politickým zájmům - je i porušením akademické integrity.

Jako možné řešení dilematu mezi tradičním a rozšířeným pojetím akademické svobody, z nichž ani jedno není z výše uvedených důvodů zcela uspokojivé, se tak nabízí založení obsahu akademické svobody právě na konceptu akademizace, který lze pokládat za klíčový prvek normativní struktury akademické profese. Takto pojímaná akademická svoboda by nebyla požadavkem apolitičnosti akademické profese ani požadavkem možnosti podřízení akademických zájmů zájmům politickým, ale byla by zkrátka a dobře právem na výkon akademické profese v souladu s jejími fundamentálními normativními principy - nebyla by ničím větším ani menším. Akademická svoboda by za těchto okolností byla nenarušena tehdy, když by akademikům nebylo nijak bráněno ve výkonu jejich profese v souladu s těmito normami, a k jejímu narušení by naopak docházelo v těch případech, kdy by jim takovýto výkon akademické činnosti byl znemožňován. Takové pojetí akademické svobody by plně akceptovalo nevyhnutelně „politickou“ povahu akademické praxe, ale současně by zachovávalo ostrou hranici mezi akademií na jedné straně a politikou na straně druhé spočívající ve fundamentální vzájemné odlišnosti normativních struktur obou oblastí. Podrobnější rozpracování této konceptuální alternativy, jakož i její důkladnější komparace s tradičním a rozšířeným pojetím akademické svobody, ovšem již přesahuje rámec této studie, a proto zde tento alternativní přístup k výkladu akademické svobody může být toliko nastíněn. ${ }^{17}$

\footnotetext{
${ }^{16}$ Zcela stejným způsobem se k otázce vzájemného vztahu mezi akademií a politikou staví i Weberův žák, filosof Karl Jaspers (viz např. Jaspers 2015: 368). Pro podrobnější rozbor Jaspersových úvah na toto téma viz Prázný (2015).

${ }^{17}$ Tomuto záměru se nicméně v poněkud širším rozsahu věnuji v Benda (2020).
} 


\section{Závěr}

Akademická svoboda byla $\mathrm{v}$ úvodní části tohoto příspěvku představena jako koncept, který byl zaveden za účelem ochrany akademické činnosti před externími - politickými, ekonomickými, nebo jinými - vlivy, jež mohou narušovat akademickou autonomii, a znemožňovat tak akademickým institucím s plnou integritou vykonávat svoji funkci spočívající na osvícenských ideálech racionality, objektivity a pravdy. Jedná se tedy o svobodu profesionální, a to v tom smyslu, že je inherentně spjata s výkonem akademického povolání, jehož profesionální obsah determinuje i obsah akademické svobody samé: jestliže je akademická svoboda souborem práv, která mají akademikovi garantovat nezbytné podmínky k odpovědnému výkonu akademické profese, pak konkrétní způsob, jakým je pojímána náplň akademické profese, sehrává určující roli i při výkladu vlastního obsahu akademických svobod. Úvahy o akademické svobodě tedy v tomto ohledu z principu nelze oddělit od obecnějších úvah ohledně funkce akademie jako takové a stejně jako by s případnými proměnami společenské role akademie bylo nutně spojeno i adekvátní redefinování obsahu akademické svobody, tak mohou odlišné interpretace akademické svobody vést ke změnám v uvažování ohledně náplně akademické profese a obecně ohledně vlastního účelu a smyslu akademických institucí.

Prosazování „rozššřreného“ pojetí akademické svobody, které k odpovědnostem akademického pracovníka připisuje odpovědnost politickou, se na tomto pozadí jeví jako problematické - ba nebezpečné - právě z toho důvodu, že fundamentální epistemickou funkci akademických institucí podřizuje funkci politické. Jak jsem se v této práci snažil ukázat, v základech tohoto pojetí se přitom nacházejí legitimní teoretické důvody. Jestliže jsou osvícenské pojmy racionality, objektivity a pravdy, na nichž spočívá tradiční pojetí akademické svobody, ve skutečnosti politickými kategoriemi a představa akademie jako politicky neutrální a autonomní „slonovinové věže“ je beznadějnou iluzí, zahrnutí politických faktorů do akademického rozhodování a odpovídající rozšíření obsahu akademické svobody se zdá být zcela logickým a samozřejmým východiskem. $\mathrm{Z}$ důvodi̊, které jsem se v textu pokusil popsat, by ale jeho nekritické přijetí bylo př́liš unáhlené. Problematičnost „rozššřreného“ pojetí akademické svobody spočívá v tom, že z rozboru reálné povahy akademické praxe - tedy z roviny deskriptivní - vyvozuje normativní závěry ohledně toho, jakou podobu by akademická praxe mít měla. Takový postup ovšem již z logického hlediska není korektní. Přestože má akademická praxe ve světle dostupných analýz nevyhnutelně politickou povahu a nelze ji od politických vlivů izolovat, není s politickou praxí identická, ale odlišuje se od ní právě svojí specifickou normativní strukturou, v níž ideály racionality, objektivity a pravdy jakkoliv se fakticky jedná o politické kategorie - sehrávají roli normativních aspirací, jež charakterizují autentickou akademickou činnost a odlišují ji od činností jiného druhu. To se názorně ukazuje na představě akademické praxe, v jejímž rámci by byl normativní význam těchto epistemologických ideálů potlačen ve prospěch ideálů politických, jako je tomu v např́ḱlad v př́padě Denise Rancourta a jeho praktikování „akademického squattingu“. Jakkoliv má tedy akademická praxe fakticky politickou povahu, její politizace i na normativní úrovni by de facto znamenala konec akademie v její stávající podobě a její radikální proměnu z instituce usilující o nezaujatost, objektivitu a politickou nezávislost v instituci otevřeně politickou. Přijetí „rozššřeného“ pojetí akademické svobody by bylo opodstatněné pouze $\mathrm{v}$ př́padě, že by akademie skutečně měla být takovou politickou institucí. Jestliže ale za jednu z klíčových charakteristik akademie budeme pokládat právě její úsilí o politickou neutralitu, jakož i její normativní ideály racionality, objektivity a pravdy, které se nacházejí v základech tradičního pojetí akademické svobody, není sebemenší důvod, proč by měla být akademická svoboda v jakémkoliv ohledu „rozšiřována“ a proč by měla zahrnovat i právo akademika jako akademika se v rámci výkonu své profese politicky angažovat za (jakkoliv prospěšné a žádoucí) politické ideály. Jako občan disponuje akademik všeobecnými politickými svobodami k tomu, aby mohl mimo svoji profesi jednat a obhajovat názory dle svého 
vlastního politického přesvědčení; jako akademik však musí v rámci výkonu své profese usilovat o politickou neutralitu, jinak už se nepodílí na činnosti akademické, nýbrž politické.

Navzdory politické povaze akademické praxe a nemožnosti jejího izolování před politickými, ekonomickými a jinými externími vlivy ovšem „rozššřené“ pojetí akademické svobody není jedinou možnou alternativou vůči tradičnímu osvícenskému pojetí. Jestliže budeme souhlasit s Weberem v tom, že odlišnost akademické profese spočívá v její normativní struktuře, akademická svoboda může být chápána zkrátka a dobře jako soubor práv garantujících akademickým pracovníkům možnost vykonávat tuto profesi v souladu s př́islušnými akademickými profesionálními normami, tj. v souladu s imperativem „akademizace“. Ve shodě s důvody, které původně vedly k jejímu zavedení, by se tak akademická svoboda vztahovala toliko k profesionální odpovědnosti akademických pracovníků, jež se od jejich sociální či politické odpovědnosti zásadně odlišuje. Na fundamentální rozdíl mezi akademickými a politickými záležitostmi a nezbytnost jejich vzájemného rozlišení ostatně již před padesáti lety výstižně upozornil filosof vědy Imre Lakatos ve své odpovědi na otázku ohledně společenské odpovědnosti vědy:

Věda jako taková podle mého názoru nenese žádnou sociální odpovědnost. Je to společnost, kdo nese odpovědnost - odpovědnost za zachování apolitičnosti a nezávislosti vědecké tradice a za zajištění podmínek nezbytných $\mathrm{k}$ tomu, aby věda mohla směřovat k pravdě způsobem, který je determinován výlučně jejím vlastním vnitřním životem. Vědec jakožto občan samozřejmě určitou odpovědnost nese, stejně jako všichni ostatní občané, a to za dohlédnutí na to, že budou vědecké poznatky použity k politicky i společensky prospěšným a žádoucím účelům. To je však již odlišný, samostatný problém, jehož řešení náleží do oblasti politiky (Lakatos 1978: 258; zvýraznění v originále).

Pojetí akademické svobody založené na imperativu akademizace vychází právě z takového rozlišení. V tomto ohledu se nepochybně může jevit jako podstatně méně atraktivní než pojetí „rozšířené“; domnívám se nicméně, že zahrnuje všechny nezbytné profesionální svobody, které jsou k odpovědnému výkonu akademické profese potřeba.

\section{Bibliografie}

AAUP. 1915. „AAUP's 1915 Declaration of Principles. “ [online] UIUC AAUP [cit. 11. 10. 2020]. http:// www.aaup-ui.org/Documents/Principles/Gen_Dec_Princ.pdf.

AAUP. 1940. „Statement of Principles on Academic Freedom and Tenure." [online] AAUP [cit. 11. 10. 2020]. https://www.aaup.org/file/1940\%20Statement.pdf.

Adorno, T. W., M. Horkheimer. 2009. Dialektika osvícenství: filosofické fragmenty. Praha: OIKOYMENH. Barendt, E. 2010. Academic Freedom and the Law. Oxford: Hart Publishing.

Barnes, B. 1974. Scientific Knowledge and Sociological Theory. London: Routledge \& Kegan Paul.

Benda, L. 2020. Akademická svoboda jako filosofický problém: pravda, spravedlnost a profesionální odpovědnost. Praha: Sociologické nakladatelství (SLON).

Besley, T., M. A. Peters. 2005. „The Theatre of Fast Knowledge: Performative Epistemologies in Higher Education." The Review of Education, Pedagogy, and Cultural Studies 27: 111-126, https://doi.org/ 10.1080/10714410590963811.

Bilgrami, A., J. R. Cole (eds.). 2015. Who's Afraid of Academic Freedom? New York: Columbia University Press, https://doi.org/10.7312/columbia/9780231168809.001.0001.

Bloor, D. 1976. Knowledge and Social Imagery. London: Routledge \& Kegan Paul.

Butler, J. 2006. „Israel/Palestine and the paradoxes of academic freedom." Radical Philosophy 135: 8-17.

Butler, J. 2015. „Exercising Rights: Academic Freedom and Boycott Politics.“ Pp 293-315 in A. Bilgrami, J. R. Cole (eds.). Who's Afraid of Academic Freedom? New York: Columbia University Press, https://doi.org/10.7312/columbia/9780231168809.003.0014. 
Butler, J. 2017. „Academic Freedom and the Critical Task of the University." Globalizations 14 (6): 857861, https://doi.org/10.1080/14747731.2017.1325168.

Butler, J. 2018. „The Criminalization of Knowledge: Why the struggle for academic freedom is the struggle for democracy." [online] The Chronicle of Higher Education, 27. 5. 2018 [cit. 11. 10. 2020]. https://www.chronicle.com/article/The-Criminalization-of/243501.

Butler, J., B. Ertür. 2017. „In Turkey, academics asking for peace are accused of terrorism. “ [online] The Guardian, 11. 12. 2017 [cit. 11. 10. 2020]. https://www.theguardian.com/commentisfree/2017/dec/11/ erdogan-turkey-academics-terrorism-violence-kurdish-people.

Collins, H. 1985. Changing Order: Replication and Induction in Scientific Practice. London: Sage.

Collins, H., R. Evans. 2017. Why Democracies Need Science. Cambridge: Polity.

Erdélyi, Á. 2018. „Update: The Lukács Archive has been closed." [online] Climate 8 Capitalism, 25. 6. 2018 [cit. 11. 10. 2020]. https://climateandcapitalism.com/2018/06/25/update-the-lukacs-archivehas-been-closed/.

Drummond, S. G. 2013. Unthinkable Thoughts: Academic Freedom and the One-state Model for Israel and Palestine. Vancouver: University of British Columbia Press.

Feyerabend, P. K. 2001. Rozprava proti metodě. Praha: Aurora.

Fish, S. 2014. Versions of Academic Freedom: From Professionalism to Revolution. Chicago \& London: University of Chicago Press, https://doi.org/10.7208/chicago/9780226170251.001.0001.

Fish, S. 2015. „Academic Freedom and the Boycott of the Israeli Universities." Pp 275-292 in A. Bilgrami, J. R. Cole (eds.). Who's Afraid of Academic Freedom? New York: Columbia University Press, https://doi.org/10.7312/columbia/9780231168809.003.0013.

Foster, J. G., A. Rzhetsky, J. A. Evans. 2015. „Tradition and Innovation in Scientists' Research Strategies.“ American Sociological Review 80 (5): 875-908, https://doi.org/10.1177/0003122415601618.

Hayes, D., R. Wynyard. 2002. The McDonaldization of Higher Education. London: Bergin \& Garvey.

Heywood, A. 2005. Politická teorie. Praha: Eurolex Bohemia.

Horowitz, D. 2006. The Professors: The 101 Most Dangerous Academics in America. Washington DC: Regnery Publishing.

Horowitz, D. 2009. Indoctrination U.: The Left's War Against Academic Freedom. New York \& London: Encounter Books.

Horowitz, D., J. Laksin. 2009. One-Party Classroom: How Radical Professors at America's Top Colleges Indoctrinate Students and Undermine Our Democracy. New York: Crown Forum.

Humboldt, W. v. 2015. „O vnitřní a vnější organizaci vyšších vědeckých ústavů v Berlíně." Pp 339-348 in J. Chotaš, A. Prázný, T. Hejduk a kol. Moderní univerzita: Ideál a realita. Praha: Filosofia.

Chotaš, J. 2015. „Idea moderní univerzity: Napoleon a Humboldt.“ Pp 69-95 in J. Chotaš, A. Prázný, T. Hejduk a kol. Moderní univerzita: Ideál a realita. Praha: Filosofia.

Chotaš, J., A. Prázný, T. Hejduk a kol. 2015. Moderní univerzita: Ideál a realita. Praha: Filosofia.

Jaspers, K. 2015. „Národ a univerzita.“ Pp 365-375 in J. Chotaš, A. Prázný, T. Hejduk a kol. Moderní univerzita: Ideál a realita. Praha: Filosofia.

Kent, L., S. Tapfumaneyi. 2018. „Hungary's PM bans gender study at colleges saying ,people are born either male or female، " [online] CNN, 19. 10. 2018 [cit. 11. 10. 2020]. https://edition.cnn.com/2018/10/19/ europe/hungary-bans-gender-study-at-colleges-trnd/index.html.

Kremakova, M. 2016. „The ,New Spirit of Academic Capitalism': Can Scientists Create Generative Critique from Within?" Teorie vědy 38 (1): 27-51, https://doi.org/10.31219/osf.io/zvspw.

Kuhn, T. S. 1957. The Copernican Revolution: Planetary Astronomy in the Development of Western Thought. Cambridge (MA): Harvard University Press.

Kuhn, T. S. 1997. Struktura vědeckých revolucí. Praha: OIKOYMENH.

Lakatos, I. 1978. „The Social Responsibility of Science." Pp 256-258 in týž, Mathematics, Science and Epistemology. Philosophical Papers Volume 2. Cambridge: Cambridge University Press, https://doi.org/ 10.1017/CBO9780511624926.015.

Latour, B. 1988. The Pasteurization of France. Cambridge (MA): Harvard University Press.

Latour, B., J. Woolgar. 1986. Laboratory Life: The Construction of Scientific Facts. Princeton (NJ): Princeton University Press, https://doi.org/10.1515/9781400820412.

Longino, H. 1990. Science as Social Knowledge: Values and Objectivity in Scientific Inquiry. Princeton: Princeton University Press, https://doi.org/10.1515/9780691209753. 
Magna Charta evropských univerzit. [online] Observatory Magna Charta Universitatum [cit. 11. 10. 2020]. http://www.magna-charta.org/resources/files/the-magna-charta/czech.

Marcuse, H. 1992. Jednorozměrný člověk. Praha: Naše vojsko.

Müller, R. 2014. „Racing for What? Anticipation and Acceleration in the Work and Career Practices of Academic Life Science Postdocs." Forum: Qualitative Social Research 15 (3): nestr., https://doi.org/ $10.17169 /$ fqs- 15.3 .2245$.

Oppenheim, M. 2018. „Hungarian Prime Minister Viktor Orban bans gender studies programmes.“ [online] Independent, 24. 10. 2018 [cit. 11. 10. 2020]. https://www.independent.co.uk/news/world/ europe/hungary-bans-gender-studies-programmes-viktor-orban-central-european-university-budapesta8599796.html.

Pappe, I. 2010. Out of the Frame: The Struggle for Academic Freedom in Israel. London: Pluto Press.

Parker, M., D. Jary. 1995. „The McUniversity: Organization, Management and Academic Subjectivity." Organization 2 (2): 319-338, https://doi.org/10.1177/135050849522013.

Polanyi, M. 1951. „Foundations of Academic Freedom." Pp 39-58 in M. Polanyi. The Logic of Liberty. Indianapolis: Liberty Fund.

Prázný, A. 2015. „Univerzita jako republika učenců. Idea univerzity u Karla Jasperse. “ Pp 197-243 in J. Chotaš, A. Prázný, T. Hejduk a kol. Moderní univerzita: Ideál a realita. Praha: Filosofia.

Rorty, R. 1994. „Does Academic Freedom Have Philosophical Presuppositions?“ Academe 80 (6): 52-63, https://doi.org/10.2307/40251372.

Shapin, S. 1994. The Social History of Truth: Civility and Science in Seventeenth-Century England. Chicago \& London: University of Chicago Press, https://doi.org/10.7208/chicago/9780226148847.001.0001.

Shapin, S., S. Schaffer. 1985. Leviathan and the Air-Pump: Hobbes, Boyle, and the Experimental Life. Princeton: Princeton University Press.

Shils, E. 2015. „Idea univerzity: Překážky a možnosti v dnešní společnosti.“ Pp 383-399 in J. Chotaš, A. Prázný, T. Hejduk a kol. Moderní univerzita: Ideál a realita. Praha: Filosofia.

Shore, C., S. Wright. 2000. "Coercive Accountability: The Rise of Audit Culture in Higher Education." Pp 57-89 in M. Strathern (ed.). Audit Cultures: Anthropological Studies in Accountability, Ethics, and the Academy. London: Routledge.

Slaughter, S., L. L. Leslie. 1997. Academic Capitalism: Politics, Policies, and the Entrepreneurial University. Baltimore: Johns Hopkins University Press.

Slaughter, S., G. Rhoades. 2004. Academic Capitalism and the New Economy: Markets, State, and Higher Education. Baltimore: Johns Hopkins University Press.

Stone, G. R. 2015. „A Brief History of Academic Freedom.“ Pp 1-9 in A. Bilgrami, J. R. Cole (eds.). Who's Afraid of Academic Freedom? New York: Columbia University Press, https://doi.org/10.7312/ columbia/9780231168809.003.0001.

Weber, M. 1998. „Věda jako povolání.“ Pp 108-132 in M. Weber. Metodologie, sociologie, politika. Praha: OIKOYMENH.

Williams, J. 2016. Academic Freedom in an Age of Conformity: Confronting the Fear of Knowledge. New York: Palgrave, https://doi.org/10.1057/9781137514790.

Zimmer, R. J. 2015. „What Is Academic Freedom For?" Pp 239-246 in A. Bilgrami, J. R. Cole (eds.). Who's Afraid of Academic Freedom? New York: Columbia University Press, https://doi.org/10.7312/ columbia/9780231168809.003.0011.

\section{O autorovi}

Libor Benda je odborným asistentem na Katedře filozofie Fakulty filozofické Západočeské univerzity v Plzni. Tematické oblasti, jimiž se zabývá v rámci své výzkumné činnosti, se nacházejí na pomezí filosofie a sociologie vědy. Patři mezi ně zejména sociální, politické a ekonomické aspekty vědecké praxe, vztah vědy a demokracie, odbornost a problematika akademické svobody. ORCID: https://orcid.org/0000-0001-56263297. 


\section{Summary}

The paper provides a critical discussion of the attempts to redefine the concept of academic freedom in political terms, and of the relationship between academia and politics in general. It starts from the observation that in the course of the ongoing debate on academic freedom, the traditional interpretation of this concept as a freedom from political and other external pressures that would compromise academic integrity - an interpretation centred around the normative ideal of politically neutral "academia-as-ivory-tower" has been increasingly disputed, as it can only be fully realized in social conditions where fundamental democratic principles and human rights, such as intellectual freedom or freedom of speech, are respected in the first place. Against this background, an argument has been developed that academic freedom cannot be separated from these general political freedoms and that its traditional understanding in terms of autonomy, political neutrality, and disinterestedness should be replaced by an "extended", politicized understanding thereof. Its proponents argue that rather than providing academics with the right to perform their professional duties in a disinterested, politically neutral fashion, the "extended" concept of academic freedom should provide them with the right to promote particular political ideals and values, as these form a fundamental part of professional academic obligations. This paper develops a critical analysis of this "extended" concept of academic freedom and points out its theoretical shortcomings, as well as its potentially dangerous consequences with regard to the understanding of both academic freedom and academia itself. It claims that while the arguments behind this concept are theoretically sound, and thus deserve serious attention, the particular way they are interpreted and the consequences drawn therefrom for thinking about the meaning and content of academic freedom prove to be difficult to justify.

The paper begins with a brief outline of the history of academic freedom and a discussion of the original motives that stimulated its development and assertion as a set of fundamental rights whose purpose is to guarantee the capacity of academic institutions to perform their scientific and educational function with full professional integrity. Being a concept whose content is inherently linked to the meaning and purpose of academia itself, academic freedom in its original sense - centred around the Enlightenment notions of rationality, objectivity, and truth - has become increasingly difficult to justify due to the deconstruction and relativization of these epistemological concepts in the second half of the $20^{\text {th }}$ century. As the epistemological function of academic freedom has been cast into doubt, and the traditional ideal of value-free academia has been replaced by the view of academia as "politics continued by other means", a different line of argument has been developed in favour of redefining the purpose of both academia and academic freedom in political terms. This politicized, "extended" understanding of academic freedom is outlined in detail in the following section via an analysis of the respective writings of Judith Butler, its leading contemporary proponent and one of the key long-term participants in the ongoing debate on academic freedom. The paper focuses in this regard predominantly on her contributions to the debate on the Palestinian Campaign for the Academic and Cultural Boycott of Israel (PACBI), an initiative launched by Palestinian academics and intellectuals in 2004 as a peaceful protest against the Israeli military occupation and colonization of the West Bank and Gaza. Drawing on this debate, the paper discusses Butler's systematic critique of the traditional apolitical understanding of academic freedom and outlines her argument for the inclusion of particular political responsibilities among the professional responsibilities of academics, as well as for the appropriate extension of academic freedom to include the right of academics to fulfil these political obligations as part of their profession. A critical analysis of this politicized view of academic freedom is subsequently provided in the next section. It is argued that while the theoretical reasons behind the "extended" concept of academic freedom cannot be ignored and demand serious attention, as they provide a valuable descriptive account of the actual nature of academic practice (i.e. what academia is), it is logically fallacious to draw normative consequences therefrom (i.e. what academia should be). The paper claims that in spite of academia's inevitably political nature, academic practice is sharply differentiated from actual politics by its embeddedness in a specific normative structure, in which the ideals of rationality, objectivity, and truth - however political these categories may be - play the role of normative aspirations that have historically made academia what it is. This is illustrated by the idea of academic practice in which the normative significance of these epistemological ideals would be suppressed in favour of political ones, as in the case of Denis Rancourt and his practice of "academic squatting". Thus, even though the paper does not dispute the inherently political nature of academic practice, it argues that the explicit politicization of academia on the normative level - as suggested by the "extended" concept of academic freedom - would 
mean the end of academia in its present form and its radical transformation from an institution striving for impartiality, objectivity and political independence into an openly political institution.

Rejecting the "extended" concept of academic freedom while simultaneously agreeing with its criticism of academic freedom as traditionally conceived, the paper concludes with a suggestion of an alternative approach to the concept of academic freedom, drawing on Max Weber's differentiation between academic and political practice, outlined in his classic lecture "Science as a Vocation", as well as on Stanley Fish's concept of "academicizing". To the extent that the distinctiveness of the academic profession can be located in its specific normative structure, the paper argues that academic freedom ought to be understood as a set of rights that enable academics to practice their profession in accordance with academic professional standards. Academic freedom thus conceived allows for the political nature of academic practice without simultaneously reducing academia to mere "politics continued by other means". Taking into account only the professional responsibility of academics, which is fundamentally different from their social or political responsibilities, such interpretation of academic freedom is likely to rehabilitate the original meaning and purpose of the concept, which is to keep academic integrity intact by defending academia as it is, not by changing it. 